\title{
Species composition and plant use in old urban homegardens in Rio Claro, Southeast of Brazil
}

\author{
Mayra Teruya Eichemberg ${ }^{1}$, Maria Christina de Mello Amorozo² e Leila Cunha de Moura ${ }^{3}$
}

Received: July 22, 2008. Accepted: March 24, 2009 RESUMO - (Composição de espécies e uso de plantas em quintais urbanos antigos de Rio Claro, Sudeste do Brasil). Com base no enfoque etnobotânico,
este estudo procurou caracterizar os quintais urbanos antigos de Rio Claro, realizando um levantamento da riqueza de espécies vegetais e seus usos, em 17
domicílios selecionados aleatoriamente. Os dados foram coletados por meio de entrevistas semi-estruturadas, estruturadas e coleta de plantas. Encontrou-se
um total de 410 espécies, distribuídas em 97 famílias botânicas, constatando-se uma alta diversidade de espécies lenhosas, tanto arbóreas como arbustivas
$\left(\mathrm{H}^{\prime}=1,66\right.$ e $\left.\mathrm{J}=0,86\right)$. Foram levantadas 257 espécies de uso ornamental, 98 alimentares e 93 medicinais. Em vista do grande número de espécies encon-
tradas para as principais categorias de uso, pode-se concluir que os quintais desempenham importantes funções no âmbito local das famílias entrevistadas,
contribuindo para a produção de alimentos e de medicamentos para consumo próprio, e também desempenhando uma importante função estética graças à
variedade de suas plantas ornamentais. A riqueza desses quintais pode estar relacionada com a origem rural e cultural dos proprietários, que ainda mantêm
uma tradição de cultivo. Verificou-se que os produtos advindos dos quintais contribuíram para a variação da dieta alimentar dos informantes, representando
um potencial promissor para a melhoria da alimentação da população.

Palavras-chave: quintais, etnobotânica, diversidade

ABSTRACT - (Species composition and plant use in old urban homegardens in Rio Claro, Southeast of Brazil). This study, based on the ethnobotanical approach, looked for to characterize the ancient urban home gardens in Rio Claro, municipality located in the Southeast of Brazil, carrying out a survey of the wealth of vegetal species and their uses, in 17 households selected randomly. The data had been collected by means of semistructured and structured interviews and by the gathering of plants. It was verified a total of 410 species, distributed in 97 botanical families, evidencing a high diversity of ligneous species, such as trees and shrubs $\left(H^{\prime}=1,66\right.$ and $\left.J=0.86\right)$. There were surveyed 257 species for ornamental use, as well as 98 for alimentary and 93 for medicinal uses. Considering the great number of species found for the main categories of use, it can be inferred that the home gardens play important functions for the interviewed families, contributing for the food and medicine production destined for the consumption by the families themselves, and also playing an important esthetic function thanks to the variety of their ornamental plants. The wealth of these home gardens may be related to the rural origin and to the culture of the owners, who still keep a cultivation tradition. It was found that the products obtained from the home gardens contributed for the diet's variety of the informants, representing a promising potential for the improvement of the population alimentation.

Key words: home garden, ethnobotany, diversity

\section{Introduction}

Research involving biological diversity in urban areas has intensified in recent years and turned its attention mainly to locales that maintain a richness of vegetation and animals, such as parks, arboretums, flower gardens, and homegardens. The species diversity sheltered by these locales provide resources, and alternative resources, for food, decoration, construction, and medicinal uses (Brito \& Coelho 2000; Semedo \& Barbosa 2007; Amaral \& Guarim-Neto 2008), as well as contributing to flood control and protecting against soil erosion (Soemarwoto 1987; Brito \& Coelho 2000).

With the development of the environmental sciences, planners began to emphasize the importance of interrelations between human beings and nature in the urban environment, and consequently, the importance of homegardens, or yards, as these, while they are becoming more and more rare in most large metropolises, continue to be, for a growing number of urban dwellers, the most immediate link with nature (Madaleno 2001a; 2001b; Amaral \& Guarim-Neto 2008). As a result, ethnobotany, in particular, has dedicated increasing attention to the theme of conservation of homegarden biodiversity.

The diversity found in homegardens is a source of genetic variability (Soemarwoto et al. 1985; Valle 2000; Semedo \& Barbosa 2007; Amaral \& Guarim-Neto 2008) that has been accumulated by the local populations, constituting a valuable patrimony for food security and even a source of genetic material for the improvement of species for commercial purposes. This genetic stock is therefore very relevant for agricultural sustainability over the long term (Torquebiau 1992). In many situations, homegardens shelter innumerable old species and varieties of domestic plants that are no longer cultivated by modern mechanized agriculture and, therefore, are not available commercially. The choice of species depends upon the personal preference and alimentary, aesthetic, and medicinal necessities, and it is also related to socioeconomic and cultural factors, as well as to the age group of familiar cycle. (Lamont et al. 1999; Brito \& Coelho 2000; Santhakumar 2000; Blanckaert et al. 2004 ).

In fact, the importance of homegardens as foci of biodiversity conservation will have to intensify in the years ahead. Although rarely formally assessed, urban and peri-urban biodiversity will come to play an increasingly significant role in human activities, since it is estimated that by 2030 , about $61 \%$ of the world population will live in cities (United Nations 2004). In Brazil, according to the population survey Censo of 2000 (IBGE 2002), 81\% of the population is already urban. However, once this figure includes habitants of municipalities with predominantly rural characteristics, such as little urbanized area and economy linked to the direct

\footnotetext{
1 Centro de Ensino Superior do Oeste, Universidade do Estado de Santa Catarina, Chapecó - SC, Brasil

2 Departamento de Ecologia, Universidade Estadual Paulista, Rio Claro - SP, Brasil

3 Corresponding Author: eichemberg@yahoo.com.br
} 
use of the natural resources, some authors believe that this IBGE figure is overestimated, and that $60 \%$ Brazilians live, effectively, in the urban web (Veiga 2003).

The municipality of Rio Claro is located at an advanced agroindustrial region, in which predominate the great monocultures, and its population lives, almost in its totality, in the urban area. Within this context, homegardens may be on their way to constituting the last holdout of the rich agrobiodiversity created and maintained by local and neighboring farmers.

The objective of this paper paper was to realize an ethnobotanic survey in old urban homegardens in Rio Claro with respect to the following main aspects: a) the composition of cultivated plants and their respective uses; b) the diversity of tree and shrub species present in each homegarden; c) the floristic similarity among homegarden; and d) the correlation between species richness and each one of the following variables: homegardens age, size of the homegarden, and monthly family income.

\section{Material and method}

\section{Study area}

The municipaliy of Rio Claro is located in central São Paulo (22 $24^{\prime} \mathrm{S}$ and $47^{\circ} 31^{\prime} \mathrm{W}$ ) $180 \mathrm{~km}$ from the state capital, São Paulo (Fig. 1). The climate in the region is tropical, with two well-defined seasons ("Cwa", according to the Köppen classification). The vegetative cover is formed of tropical broadleaf forest and gallery forest, but in restricted areas. The savannah is practically extinct (Matias 1989). Soil use in the municipality is dedicated mainly to sugar cane plantations, orange groves, and pastureland, with a small amount used for the cultivation of other crops, such as corn, rice, and cotton.

The population of Rio Claro is $168,087,96 \%$ of which is concentrated in the urban area (IBGE 2002). The economically active inhabitants are employed mainly in industry, which is concentrated in the northern region of the city, and commercial activities, distributed throughout the city, followed by liberal professionals and self-employed. The elderly population resides mainly in the older neighborhoods of the city where the longer-term residents are also concentrated.

\section{Method}

Households with older homegardens located in the urban region of Rio Claro were sampled. These older homegardens correspond to the green areas of households within the city limits and are characterized by the presence of tree and shrub species that have been maintained for 25 years or longer, and whose residents are more than 50 years old.

Based on the map of the evolution of urban space in Rio Claro (Troppmair 1992) (Fig.2), neighborhoods that had been formed until the year 1945 were selected, totaling seven neighborhoods. It was assumed that older homes with preserved homegardens would be found in these neighborhoods. Of the 380 squares on the map that satisfied these requisites, corresponding to 380 city blocks, 60 were randomly selected using a standard table of random numbers. By means of field recognition, it was verified which were the dwellings that had old homegardens. Of those squares that were randomly selected, only 22 satisfied the above criteria. During the first two months of field work, five of the households covered their homegardens with cement or cut all the trees. Thus, the final sample was reduced to a total of 17 households.

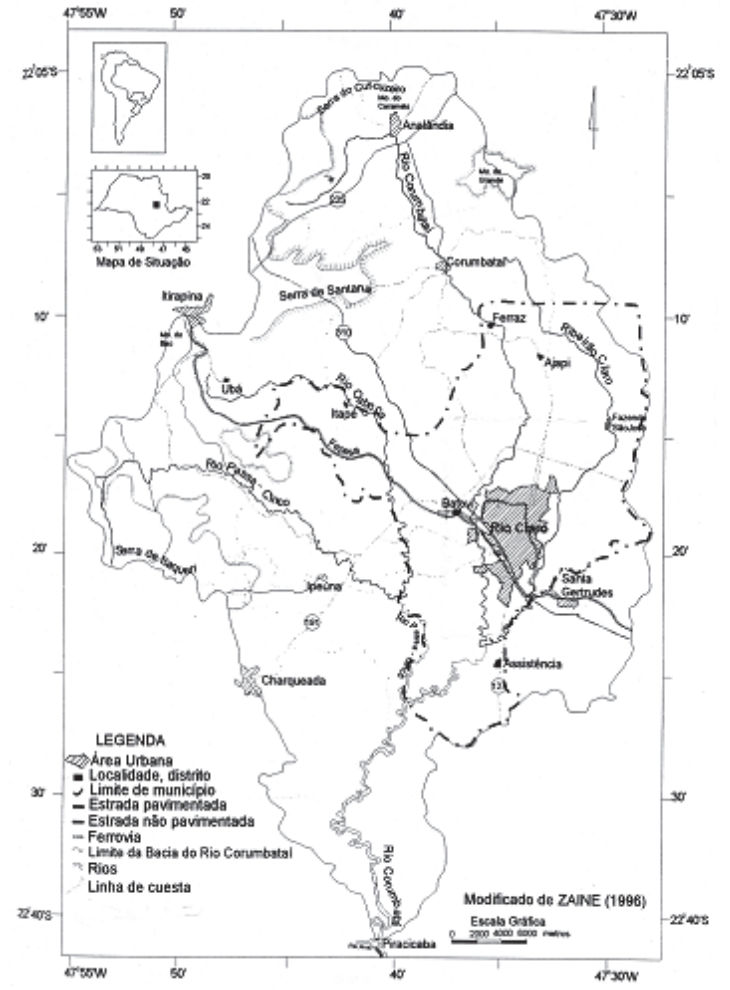

Figure 1. Map showing the location of the muncipality of Rio Claro.

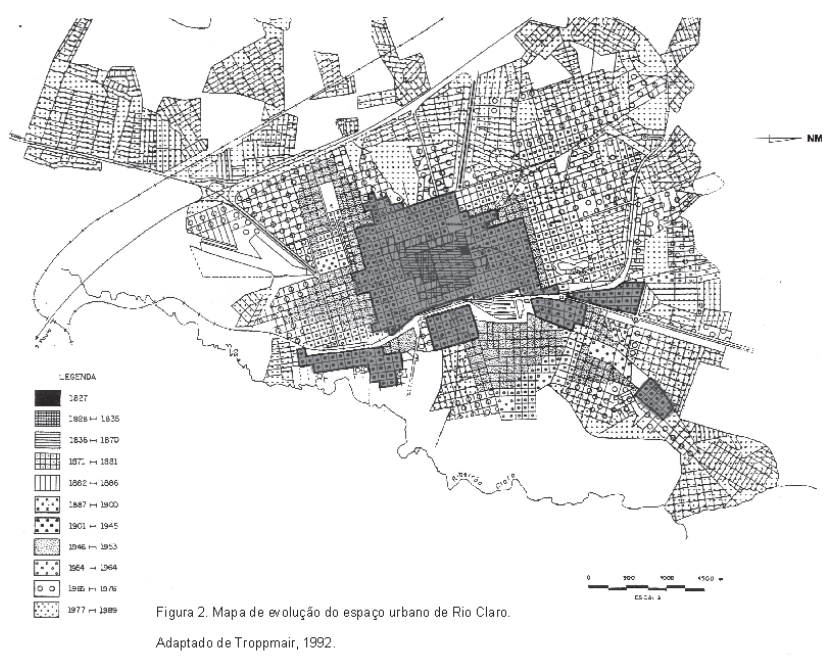

Figure 2. Map of the evolution of urban space in Rio Claro. The shaded area corresponds to the neighborhoods formed until 1945 (Troppmair, 1992).

Five men and 12 women were interviewed. All of them were descendent of immigrants from Western Europe that came to Brazil to work in coffee farms around 1840. All the informants were born in the State of São Paulo, Brazil. The most part of them (77,3\%) comes from the region of Rio Claro or from neighbour areas. The interviewees were grouped according to two origins. One of the groups included dwellers from rural origin, and their parents, or themselves, the interviewees, were workers from coffee farms. The other group includes the interviewees which were born in urban areas, but that also had a rural heritage conveyed by their parents and grandparents. 
The majority of the interviewees was constituted of people retired (59\%) from service and commerce sectors, and the remaining people were housewives (41\%). The monthly familiar income of $29 \%$ of the interviewees was lesser than 2.5 minimum wages (1SM $\cong \mathrm{U} \$ 191,00)$, and the income of $52 \%$ of the interviewees corresponds to a salary range from 2.5 to 5 minimum wages. Only $18 \%$ of the interviewees had an income between 5 and 7 minimum wages. Similar data are found in the Southeastern Region of Brazil, in which about $60 \%$ of the families receive an income in the range from 2 to 5 minimum wages per month (IBGE 2002).

Among the interviewees, the schooling was low: $9 \%$ were analphabets and $64 \%$ had not finished basic education. (between 1 and 8 years of schooling)

The studied population possessed their own houses, with average time of occupation of 47.4 years (in a range that extends from 26 to 70 years). With regards to urbanization, all the houses of the sample had access to electric energy, basic sanitation, and garbage collection.

The data collection period extended over thirteen months, from October, 2001 to November, 2002. An inventory of the plants present in the homegardens was carried out via semi-structured interviews (Bernard 1988), to collect information on the vernacular names of the plants and their uses and functions, which were categorized as follows: alimentary, medicinal, ornamental, and other uses. The vegetal species samples were recorded, collected, and included in the Herbarium Rioclarense (HRCB). Identification was done by comparison, using basic references, as well as visits to herbariums. The following botanists and specialists were also consulted: Antônio Furlan, Marco Antonio de Assis, Vinícius A. Dittrich and Cristiano Marcelo Viana Cardoso, of the Departamento de Botânica, Instituto de Biociências da UNESP, Rio Claro/SP; José Orlando de Figueiredo and Roseli B. Torres, both of the Instituto Agronômico of Campinas/SP.

For the tree and shrub species diversity analysis, all the individuals present were counted and the Shannon-Wiener Index $\left(\mathrm{H}^{\prime}\right.$ - base 10$)$ was applied, which combines the components of richness (number of species) and abundance, and Pielou Index ( $\left.\mathrm{J}^{\prime}\right)$ of equitability (relation of abundance among species), according to Krebs (1989). The diversity analyses corroborate the importance of homegardens in the maintenance of diversity and conservation of cultivated plant varieties, stimulating the realization of comparative studies of the number, composition, and organizational pattern of plant species in different regions.

To evaluate floristic similarity, with respect to the absence/presence of plant species in the homegardens studied, the Sørensen coefficient of similarity (Krebs 1989) was used, which makes it possible to verify the extent to which the homegardens are floristically similar by comparing the number of species they have in common. For the analysis of similarity, the homegardens were grouped into three categories: large $\left(>1,000 \mathrm{~m}^{2}\right)$, medium $\left(600 \mathrm{~m}^{2}\right.$ to $\left.999 \mathrm{~m}^{2}\right)$, and small $\left(<600 \mathrm{~m}^{2}\right)$.

For the correlation between species richness and the following variables: homegarden age, size of the homegarden, and monthly family income, the Kendall-Tau correlation test was applied (Siegel 1975).

\section{Results and discussion}

Species structure and composition

The homegardens studied were found to be complex units of production, with great plant richness composed of a mixture of native and exotic species. In the 17 homegardens studied, 410 species were found, distributed among 97 botanical families (Appendix 1), with the following four being the most represented in terms of number of species: Lamiaceae, Asteraceae, Araceae, and Liliaceae (Fig. 3).

The species were grouped in four categories of use, with the most frequent being predominantly ornamental (approximately $63 \%$ of the species), followed by alimentary $(24 \%)$, and medicinal (23\%). The condimental use is included in the alimentary category. The species categorized as other uses corresponded to $4.0 \%$. For $12 \%$ of the species, two or more uses were indicated.

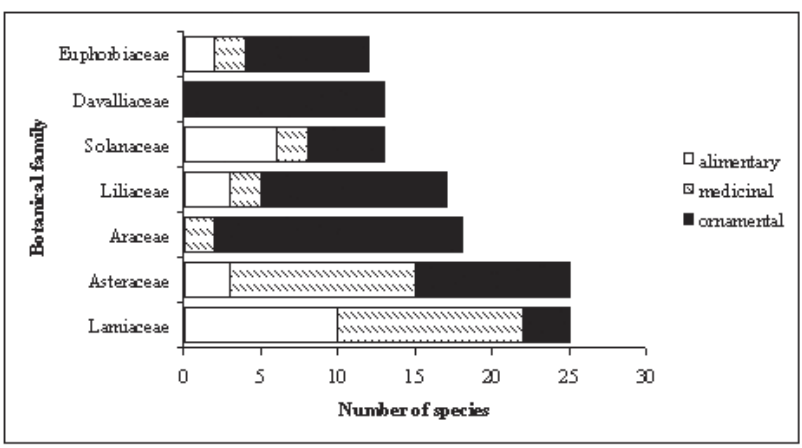

Figure 3. Most-represented botanical families in number of species per category of use.

The small number of studies on vegetation richness in urban homegardens in southeastern Brazil, and the absence of a standardized sampling procedure in the studies, makes comparison with the present study difficult. The few studies that focus on urban homegardens are related to their importance as a source of food. There are some studies from the Amazon about homegardens that allow verification of useful species which are cultivated there, including trees, shrubs, herbs, and vines, such as: Padoch \& De Jong (1991), who studied 21 homegardens in river communities of Santa Rosa in the Peruvian Amazon; Brito (1996), which included 13 agroforestry homegardens in the north of Mato Grosso; and Lima and Saragoussi (2000), who studied 16 homegardens in a floodplain region near Manaus, Amazonas, the last two in Brazil. In these studies, the most representative families in numbers of species found were: Rutaceae, Euphorbiaceae, Araceae, Asteraceae, and Solanaceae. Although these families were also recorded in the present study, there were variations in the species composition, partly due to those that were locally cultivated or natural to the region, and also due to socioeconomic and cultural factors, as well as family traditions (Soermarwoto et al. 1985; Gliessman 1990; Padoch \& De Jong 1991; Soermarwoto \& Conway 1991; Lamont et al. 1999; Brito 1996; Santhakumar 2000; Madaleno 2001b).

Plants belonging to the three main categories of use were found in all the homegardens sampled, considering the main use cited by the informants for each species (Tab. 1).

Although the shape, size and number of species varied for each homegarden, correlation analyses indicated no statistically significant associations between species richness and lot size (Kendall-Tau $=0.20, p=0.13$ ) and monthly family income (Kendall-Tau $=0.22, \mathrm{p}=0.20$ ). We could think that the greater the lot size, the greater the species richness (Lamont et al. 1999), although this relation was not found in this study, nor in the study conducted by Albuquerque et al. (2005) on the structure of homegardens in the Brazilian Northeast. Probably, the advanced age of the interviewees is a limiting factor for the cultivation of a greater number of species in bigger homegardens. In the same way, as the familiar income of the domiciles did'nt change too much, the richness of species also did'nt change significantly. 
Table 1. Number of species found, categorized according to main use, in older urban homegardens in Rio Claro.

\begin{tabular}{|c|c|c|c|c|c|c|}
\hline Homegarden & Total & Ornamental & Medicinal & Alimentary & Other uses & Size $\left(m^{2}\right)$ \\
\hline 14 & 130 & 70 & 29 & 28 & 3 & 1,040 \\
\hline 02 & 124 & 93 & 6 & 19 & 6 & 1,400 \\
\hline 01 & 88 & 34 & 7 & 44 & 3 & 715 \\
\hline 05 & 83 & 22 & 20 & 36 & 5 & 528 \\
\hline 13 & 82 & 61 & 5 & 12 & 4 & 516 \\
\hline 07 & 81 & 48 & 18 & 12 & 3 & 600 \\
\hline 17 & 76 & 38 & 13 & 21 & 4 & 428 \\
\hline 08 & 71 & 34 & 7 & 30 & 0 & 1,080 \\
\hline 06 & 63 & 32 & 7 & 22 & 2 & 2,000 \\
\hline 11 & 59 & 40 & 3 & 15 & 1 & 506 \\
\hline 10 & 52 & 21 & 12 & 19 & 0 & 440 \\
\hline 15 & 50 & 14 & 9 & 27 & 0 & 910 \\
\hline 09 & 41 & 12 & 6 & 20 & 3 & 572 \\
\hline 16 & 40 & 15 & 14 & 10 & 1 & 450 \\
\hline 03 & 36 & 18 & 5 & 12 & 1 & 800 \\
\hline 12 & 33 & 7 & 6 & 20 & 0 & 484 \\
\hline 04 & 28 & 10 & 6 & 12 & 0 & 616 \\
\hline Total & 410 & 257 & 93 & 98 & 16 & - \\
\hline Mean & 67 & 33.4 & 10.1 & 21.2 & 2.1 & 769.7 \\
\hline Standard Deviation & 29.6 & 23.5 & 6.8 & 9.4 & 1.9 & 418.1 \\
\hline
\end{tabular}

However, the correlation analysis did reveal a significant association between species richness and age of the homegardens $($ Kendall-Tau $=0.43, p=0.0071)$. This signifies that the older the homegarden, the greater the number of plant species found in it. This result corroborated by study carried out by Coomes \& Ban (2004). The acquisition and maintenance of plants over time may be one explanation for this result, together with individual, traditional, and cultural factors of the informants (Rico-Gray et al. 1990; Caballero 1992).

The similarity index showed little variation among the groups: $53 \%$ between large and medium, $52 \%$ between large and small, and $57 \%$ between medium and small homegardens. The ease of obtaining and/or cultivating some plants may be important factors in the determination of the basic composition of these homegardens. On the other hand, the differences are, probably, related to personal differences between the owners of these homegardens.

The physiognomy of the homegardens, in turn, may be determined by the species diversity of the trees and shrubs present in each homegarden. This presence is characteristic of tropical homegardens, and in the present study, we aimed to survey the diversity of the ligneous species. The Shannon-Wiener diversity index $\left(\mathrm{H}^{\prime}\right.$ - base 10$)$ value obtained for the older urban homegardens in Rio Claro was 1.66, which included 86 species, totaling 444 individuals from 36 families, with the most representative in terms of number of species being Rutaceae (10), Myrtaceae (9), and Rosaceae (9).

In agroforestry homegardens in Aripuanã, plants from all the habits were surveyed and their diversity corresponded to an index of 2.22, which represents a high diversity (Brito 1996). The Shannon-Wiener index for the homegardens studied in Rio Claro could be as high as those reported by Brito in homegardens in Aripaunã if all species found, and not only the tree and shrub species, were included.

With respect to equitability, the Pielou (J) index found was 0.86 , indicating low species dominance, and also indicating that the relation of species abundance in the homegardens tended to be equitable.

One of the factors that could explain the species diversity found in these homegardens is related to the origin of the informants, who came from the rural areas and developed their own adaptive strategies to cope with the new environment and new economic context in the city. To meet their food needs, they implanted a form of urban agriculture, which explains the presence of fruit trees and the diversity of hardwood species (Winklerprins 2002; Semedo \& Barbosa 2007).

\section{Ornamental plants}

The ornamental plant category was the most representative in number of species, with 257 species recorded, distributed among 77 families. The ornamental species richness would 
be greater if orchids and ferns of the family Polypodiaceae were included; these were present in 10 homes, but it was not possible to identify them. The existence of many hybrids, the absence of reproductive structures, and in some cases, the impossibility of collecting botanical material are three problems faced by ethnobotanists studying plants cultivated in homegardens, particularly ornamental plants.

One factor that may be related to the greater ornamental species richness is the strong female presence in the care of the homegardens sampled. The women manifest greater involvement in the cultivation of ornamental plants (an average of 40.5 species per homegarden) than do the men (an average of 19.8 species per homegarden), and show more interest and more concern for the aesthetics of the household. According to Nair (1993), the high number of ornamental plants is associated with the aesthetic role of homegardens in cities, since they are not used for subsistence in urban areas, except among low income populations (Niñez 1984). Thus, the number of ornamental plants has increased in areas near, as well as in, urban areas in response to the process of modernization and the large supply of these plants in cities (Moura \& Andrade 2007). This phenomenon has also been observed in regions where the cultivation of plants in homegardens follows a millennial tradition, as is the case of the Mayans, according to studies carried out by Rico Gray et al. (1990) and Caballero (1992) on the Yucatan Peninsula, Mexico.

The economic situation is another factor that may partially explain this result, since none of the interviewees depended solely on their homegardens for food. Therefore, they can seek plants from other categories to cultivate in their homegardens. However, the present study do not contemplate very different levels of income in the sampling, which would have made it possible to verify the existence of this relationship. Comparative studies of urban homegardens that include different social classes could contribute to this verification.

\section{Food plants}

A variety of species cultivated for eating were found in all the homegardens studied, mainly fruits, and smaller amounts of vegetables. In the food category, 98 species were found pertaining to 37 families. The number of species ranged from 10 to 44 , corresponding to a mean of 21 species per homegarden.

The botanical families with the higher numbers of species in this category were: Lamiaceae, represented by 10 species; Rutaceae and Myrtaceae, with 9 species each; and Solanaceae, with 6 species. All the alimentary species from the family Lamiaceae were used as condiments, indicating their important role in diversifying the flavor of food. The families Rutaceae, Solanaceae and Myrtaceae were also reported in studies by Brito (1996) carried out in northern Mato Grosso, and by Lima and Saragoussi, in the central
Amazon, who recognized their presence as representative of the number of food species, especially fruit trees. Despite being in such different regions, there appears to be a group of common exotic species, such as mango (Mangifera indica), papaya (Carica papaya), avocado (Persea americana), coconut (Cocos nuccifera), and some species of Citrus. In addition to these, other fruit trees have been reported in studies of tropical homegardens, such as species of the genera Spondias, Annona, Psidium and Anacardium (Rico-Gray 1990; Padoch \& De Jong 1991; Lamont et al. 1999; Lima \& Saragoussi 2000; Albuquerque et al. 2005; Semedo \& Barbosa 2007). This similarity may be related to the process of Iberian colonization, which resulted in the introduction of various species in Brazil, as well as the large migratory flow among various regions of the country, which would have quickly disseminated these species in homegarden spaces.

In the homegardens studied, the families Rutaceae and Myrtaceae were represented by species of fruit trees. The Myrtaceae family includes plants whose fruits are rarely, or relatively rarely, commercialized, such as the grumixama (Eugenia brasiliensis), the strawberry guava (Psidium cattleianum), the rose apple (Syzygium jambos), the cabelluda, or yellow jaboticaba (Myrciaria glomerata), the uvalha (Eugenia pyriformis) and cherry of the Rio Grande (Eugenia involucrata), suggesting the important role of homegardens as a source of alternative foods. All the species are native to Brazil, with the exception of the rose apple, which although it is native to India and some of the Malaysian Islands, adapted so well to tropical conditions in South America that it appears as if it were native to Brazil (Silva \& Tassara 2001). In other regions of the country, such as the Amazon, native species are represented by other families, such as the sapodilla Achras sapota (Sapotaceae), various species of Theobroma (Sterculiacaeae), and pejibaye (Bactris gasipaes) and other palm trees (Arecaceae).

It is interesting to note that these native species, originally from the savannah or other Brazilian vegetation formations, are also found in homegardens, suggesting the importance of these homegardens as a useful source of plant germplasm. With respect to genetic potential, the number of fruit species existing in Brazil exceeds 100, many of which are not conveniently exploited. Homegardens could also be spaces to experiment with native fruit trees that the majority of Brazilians are unfamiliar with, or others that have not yet adapted to the conditions in which they are cultivated, but which are on their way to doing so, thus making possible their acclimatization and domestication (Murrayama 1973; Winklerprins 2002). But together with the germplasm conserved in the homegardens, it is extremely important to maintain the knowledge regarding these species and varieties (Valle 2000).

With respect to fruit species of the Rutaceae family, the relatively high number of varieties of the genus Citrus was noteworthy (13), corresponding to 8 species, 
twice the number found by Brito (1996) in a study of 13 homegardens in Aripuanã, in the state of Mato Grosso. For the homeowners, the presence of this genus in their homegardens represents a fundamental source of Vitamin $\mathrm{C}$ in their diets. Corroborating these findings, Ambrósio et al. (1996), studying 13 rural homegardens in Vera Cruz, in the State of São Paulo, found that the sole sources of the Vitamins $\mathrm{A}$ and $\mathrm{C}$ in the diets of the informants were the fruit trees planted in their homegardens.

The acerola, which was the third most frequent fruit, is a relative newcomer to Brazil, its popularity having spread as a result of a large campaign to increase awareness regarding its advantages, possible uses, and methods of cultivation, based on studies showing that it contains 100 times the amount of Vitamin C contained in oranges and limes (CarpentieriPípolo et al. 2000). As expected, publicity regarding this fact gained the immediate attention of the population (Silva \& Tassara 2001). In the homegardens studied, the frequency of acerola (82\%) reveals the willingness of homeowners to plant new species in their homegardens that can enrich their diet when they are appropriately informed and stimulated to do so. Thus, while homeowners tend to keep traditional species planted in their homegardens, they also reveal themselves to be open to the introduction of new species, if well-structured campaigns and programs are employed to publicize the advantages and virtues of these new species, thus providing incentives for their cultivation.

It is interesting to note that the species cultivated in the homegardens sampled are, for the most part, common throughout the country. The presence of these species in homegardens in various regions of Brazil, urban and non-urban, may point to the possibility for exchange and diffusion of genetic material of fruit trees - a possibility worth exploring, especially in relation to potentially useful species (Lamont et al. 1999; Brito \& Coelho 2000; Lima \& Saragoussi 2000; Clement et al. 2001; Albuquerque et al. 2005; Semedo \& Barbosa 2007).

Despite the great richness of food species found in the older urban homegardens in Rio Claro, it was found that they were underutilized as a food security resource for homeowners, signifying a loss in food production. The presence of food plants indicates the potential for contributing to greater variation in the flavors and composition of the diet. But it should not be forgotten that, despite their underutilization, the presence and consumption of food from homegardens indicate their importance as sources of vitamins and micronutrients, as corroborated by studies carried out in Manaus by Amorozo (1981), in rural homegardens in Vera Cruz, São Paulo, studied by Ambrósio et al. (1996), and in urban homegardens in Boa Vista, Roraima (Semedo \& Barbosa 2007), and in Rosário Oeste, Mato Grosso (Amaral \& Guarim-Neto 2008).

In various regions of the world, homegardens have the function of guaranteeing subsistence, and even complementing the household income (Niñez 1984;
Cleveland \& Soleri 1989; Rico-Gray et al. 1990; Padoch \& De Jong 1991; Caballero 1992; Brito \& Coelho 2000; FAO 2004). In Brazil, to provide adequate food security for residents of households with homegardens, governmental and educational initiatives would be necessary that promote publicity programs in the media and encourage appreciation and improvement of these traditional systems of production. Only such initiatives would be able to have an impact on the awareness of the population capable of bringing homegardens back from the situation of near abandonment to which they have been relegated and recover a dynamism compatible with their immense productive potential.

\section{Medicinal plants}

The medicinal plant category consisted of 93 species, from which $32 \%$ are native from Brazil, $61 \%$ are exotic, and $7 \%$ were not identified. Theses species are distributed among 39 families, with Lamiaceae and Asteraceae presenting the largest number of species, corresponding to $34 \%$ of the total medicinal plants found in the homegardens (Appendix 1). These families were also found to be the most representative in homegardens studied by Brito (1996), in Mato Grosso, and by Silva-Almeida \& Amorozo (1998), in a district of Rio Claro. In these studies, 53 and 55 medicinal species, respectively, were found being cultivated. Thus, it can be concluded that the homegardens studied shelter a high richness of medicinal plants, a fact that may be associated with the age group of the informants, as the mean age of the sample was 73 years. In general, the elderly retain more knowledge about the use of medicinal plants, largely due to their accumulated experience, as well as their own need to use them, given their advanced age.

Most of the medicinal species present in the homegardens studied were herbs $(69 \%)$, followed by trees $(15 \%)$ and shrubs (13\%). Amorozo \& Gély (1988) also found that herbs were the most common medicinal plants used in the region of the Lower Amazon. The same has been reported in other studies, such as Jacomassi \& Piedade (1994), SilvaAlmeida \& Amorozo (1998), and Brito (1996). The great majority of medicinal species found were exotic, introduced by European immigrants, and adapted well to homegardens, being incorporated into popular knowledge.

The most frequent medicinal plants in the homegardens sampled were used mainly as sedatives (rosemary, lemongrass, and mint), analgesics for sore throat (ginger root and pomegranate), remedies for liver and stomach problems (boldo and carqueja), respiratory problems (epazote), and healing wounds (aloe). Rosemary, lemongrass, boldo, pennyroyal, and mint were also the species most reported by Jacomassi \& Piedade (1994). The authors comment that this is probably due to the fact that these plants are used to meet basic day-to-day needs. Similar results were also found by other authors in studies realized in other regions of the country, for example in the Southeast and South (Castellucci 
et al. 2000; Dorigoni et al. 2001; Garlet \& Irgang 2001; Pilla et al. 2006). Some of these species have scientifically proven pharmacological properties, such as boldo (Plectranthus barbatus) and mint (Mentha sp.) (Panizza et al. 1982; Manns 1995). Other species found in the homegardens are equally well-known in various parts of the world, such as Cymbopogon citratus (lemongrass) and Melissa officinalis (balm-mint), both used as sedatives (Cruz 1982).

Among their different uses, the large majority of the medicinal plants found in the homegardens are consumed as teas, prepared by decoction (42\%) and also by infusion $(18 \%)$. The part of the plant most commonly used in preparation is the leaf $(76 \%)$, but other parts were also observed being used (root, stem, flower, fruit, and seed).

Ailments for which the largest number of plant species were used were related to the digestive system (32), nervous system (12), and respiratory system (11). The species whose therapeutic effect acted on the nervous system were used mainly as sedatives, and also to address sleep disorders and alleviate day-to-day stress, common in urban areas. In other places in Brazil, the most common use of medicinal plants is for the treatment of ailments of the digestive and respiratory systems (Amorozo \& Gély 1988; Hanazaki et al. 1996; Silva-Almeida \& Amorozo 1998; Amorozo 2002).

Plants such as pennyroyal, Mentha pulegium, and mint, Mentha sp., were cited for the treatment of six ailments, including digestive system problems, worms, colds, and also as sedatives. Mint was also cited for the treatment of high blood pressure and pennyroyal for cough. According to Cruz (1982), pennyroyal and mint have always been traditional plants widely used by Brazilian families.

The production of medicinal plants in homegardens has relevant importance as an alternative for populations with limited access to modern medical services (Silva-Almeida \& Amorozo 1998). Although the population sampled resides in an urban area, the plants with therapeutic properties that grow in their homegardens represent a readily available resource for common, less serious afflictions, such as colds and indisposition, partially guaranteeing the well-being of the residents. The high cost of medicine and private health care is another factor that stimulates local production of the remedies grown in homegardens.

\section{Conclusions}

Old urban homegardens in Rio Claro revealed themselves to be locales with great vegetation richness, as the study of 17 of these homegardens showed the presence of 410 species distributed among 97 botanical families.

The study also showed that the richness, similarity, and diversity of plant species found in the homegardens studied are associated with the cultural background common to the homeowners, as well as the preferences and experiences acquired by them throughout their lives.
Another aspect that should be highlighted is the important role of the aesthetic function in the cultivation of plants in urban homegardens, made evident by the large number of ornamental species observed in this study. The important role of women in the cultivation of these plants and consequent diffusion of this vegetation richness should also be emphasized.

The richness found in the homegardens studied is not restricted to the number of species but manifests itself, as well, in the large number of varieties of fruit trees. Many of these fruits are neither commonly available in markets nor cultivated by commercial agriculture. A clear example of this is the large number of varieties of the genus Citrus that are preserved locally only because people plant them in their homegardens. In addition, the presence of fruits that originated in the savannah and other Brazilian vegetative formations, which in the studied region are threatened with extinction due to the pressures of large-scale agricultural activities, points to the relevant role of homegardens in the conservation of native species that originated from these habitats.

Most of the plants surveyed are exotic and widely disseminated throughout Brazil. Given the receptivity of homeowners to the introduction of new species, as clearly illustrated by the case of the acerola, dissemination of equal proportions could occur with native species if educational campaigns were implemented to encourage the population. If this receptivity were stimulated and reinforced, for example via Internet sites that map the presence of a wide range of varieties in a range of urban homegardens, this could encourage the diffusion of seedlings and seeds as well as the appreciation and dissemination of fruit varieties endowed with exceptional flavor or nutritional characteristics, for example, and perhaps even provide incentive for the establishment of alternative markets of non-conventional fruits and medicinal plants. In this sense, ethnobotanical studies allied with governmental and educational initiatives diffused by the media, could provide support for the implantation of regional programs that aim to intensify and improve the exploitation of homegardens. Such support could include incentives for the cultivation of food and medicinal plants, be they native or exotic.

The presence of fruit trees whose lineage has been conserved over the years would be enough to justify the relevance of homegardens as conservation systems for plant resources and germplasm of cultivated plants. The revitalization of the use of homegardens would be of invaluable importance for the conservation of rare species, as well as for the provision not only of resources with obvious utility to urban populations, but also of little known or little used alimentary, medicinal, and ornamental resources that could multiply the number of conventional uses of plants cultivated in homegardens.

In the meantime, the future of homegardens is uncertain. Their continued use, and even their existence, may be 
threatened due to the rapid changes occurring in their physical aspects (for example, their deactivation for the construction of garages or cemented areas, like the five homegardens deactivated during our study that composed part of our original sample) and urban land use pressure, as well as the rupture in the tradition of cultivation and care of these homegardens by new generations that are increasingly giving in to the pressures of economic development and new lifestyles, and are turning their backs to their homegardens. The present study raises the somber perspective that these homegardens, in spite of their great richness, effective and potential, could disappear from the urban scene, and with them, all the knowledge involved in their care. This valuable knowledge will be distinguished unless this prediction changes, this invaluable store is recorded and disseminated, and new generations are motivated to recover and re-energize the productive capacity of homegardens.

\section{Acknowledgements}

The authors would like to thank CAPES (Coordenação de Aperfeiçoamento Pessoal e Social) for the financial support and research scholarship, as well as the reviewers Newton Roberval Eichemberg, Maria de Lourdes Eichenberger and Anne Kepple.

\section{References}

Albuquerque, U. P.; Andrade, L. H. C. \& Caballero, J. 2005. Structure and floristics of homegardens in Northeastern Brazil. Journal of Arid Environments 62(3): 491-506.

Amaral, C. N. \& Guarim-Neto, G. 2008. Os quintais como espaços de conservação e cultivo de alimentos: um estudo na cidade de Rosário Oeste (Mato Grosso, Brasil). Boletim do Museu Paraense Emílio Goeldi 3(3): 329-341.

Amorozo, M. A. M. 1981. Alimentação em um bairro pobre de Manaus, Amazonas. Acta Amazonica 11(3): 5-43.

Amorozo, M. C. M. 2002. Uso e diversidade de plantas medicinais em Santo Antonio do Leverger, MT, Brasil. Acta Botanica Brasilica 16(2): 189-203.

Amorozo, M. C. M. \& Gély, A. 1988. Uso de plantas medicinais por caboclos do baixo Amazonas, Barcarena, PA, Brasil. Boletim do Museu Paraense Emílio Goeldi (4): 47-131.

Bernard, H.R. 1988. Research Methods in Anthropology: qualitative and quantitative approaches. Walnut Creek, C.A. AltaMira Press.

Blanckaert, I.; Swennen, R.L.; Flores, M. P.; López, R. R. \& Saade, R. L. 2004. Floristic composition, plant uses and management practices in homegardens of San Rafael Coxcatlán, Valley of Tehuacán-Cuicatlán, Mexico. Journal of Arid Environments 57: 39-62.

Brito, M. A. \& Coelho, M. F. B. 2000. Os quintais agroflorestais em regiões tropicais - unidades auto-sustentáveis. Revista Agricultura Tropical 4(1): 1-21.

Caballero, J. 1992. Maya homegardens: past, present and future. Etnoecológica 1: 35-54.

Carpentieri-Pípolo, V.; Destro, D.; Prete, C. E. C; Gonzales, M. G. N; Popper, I.; Zanatta, S. \& Da Silva, F. A. M. 2000. Seleção de genótipos parentais de acerola com base na divergência genética multivariada. Pesquisa Agropecuária Brasileira 35(8): 1613-1619.

Castellucci, S.; Lima, M. I. S.; Nivaldo, N. \& Marques, G. W. 2000. Plantas medicinais relatadas pela comunidade residente na estação ecológica de Jataí, município de Luís Antônio/SP: uma abordagem Etnobotânica. Revista Brasileira de Plantas Medicinais 3(1): 51-60.

Clement, C. R.; Noda, H.; Noda, S.N.; Martins, A. L. U. \& Silva, G. C. 2001. Recursos frutícolas na várzea e na terra firme em onze comunidades rurais do Alto Solimões, Amazonas, Brasil. Acta Amazonica 31(3): 521-527.
Cleveland, D. A. \& Soleri, D. 1989. Dryland household gardens in development. Arid-Lands-Newsletter 29: 5-9.

Coomes, O. T. \& Ban, N. 2004. Cultivated plant species diversity in home gardens of an Amazonian peasant village in northeastern Peru. Economic Botany 58(3): 420-434.

Cruz, G. L. 1982. Dicionário de plantas úteis do Brasil. Rio de Janeiro. Civilização Brasileira.

Dorigoni, P. A.; Ghedini, P. C.; Fróes, L. F.; Baptista, K. C.; Ethur, A. B. M.; Baldisserotto, B.; Burguer, M. E.; Almeida, C. E.; Lopes, A. M. V. \& Záchia, R. A. 2001. Levantamento de dados sobre plantas medicinais de uso popular no município de São João do Polêsine, RS - Relação entre enfermidades e espécies utilizadas. Revista Brasileira de Plantas Medicinais 4(1): 69-80.

Food And Agriculture Organization Of The United Nations (FAO). 2004. Household food security and community nutrition. http://www.fao. org/es/ESN/nutrition/household_gardens_en.stm

Garlet, T.M.B. \& Irgang, B.E. 2001. Plantas medicinaisutiliz adas na medicina popular por mulheres trabalhadoras rurais de Cruz alta, Rio Grande do Sul, Brasil. Revista Brasileira de Plantas Medicinais 4(1): 9-18.

Hanazaki, N., Leitão-Filho, H. F. \& Begossi, A. 1996. Uso de recursos na mata Atlântica: o caso da Ponta do Almada (Ubatuba, Brasil). Interciência 21(6): 268-276.

Heywood, V. H. 1997. Information needs in biodiversity assessments from genes to ecossystems. In: Hawksworth, P. M. K. \& Clarke, S. D. Biodiversity information: needs and options. New York: $\mathrm{CAB}$ International.

Instituto Brasileiro de Geografia e Estatística (IBGE). 2002. Brasil em números. V. 10. Rio de Janeiro.

Jacomassi, E. \& Piedade, L. H. 1994. A importância das plantas com finalidades terapêuticas e suas aplicações na cidade de Goioerê - PR. Revista UNIMAR 16(2): 335-353.

Krebs, C. J. 1989. Ecological methodology. Harper \& Row.

Lamont, S. R.; Eshbaugh, W. H. \& Greenberg, A. M. 1999. Species composition, diversity, and use of homegardens among three Amazonian villages. Economic Botany 53(3): 312-326.

Lima, R. M. B. \& Saragoussi, M. 2000. Floodplain home gardens on the central amazon in Brazil. In: Junk, W. J.; Ohly, J. J.; Piedade, M. T. F. \& Soares, M. G. M. The Central Amazon Floodplain: actual use and options for a sustainable management. Leiden. Backhuys Publishers.

Madaleno, I. M. 2001a. Cities of the future: urban agriculture in the third millenium. Food, nutrition and agriculture 29: 1-8.

Madaleno, I. M. 2001b. Urban agriculture supportive policies from two distant cities: Lisbon (Portugal) and Presidente Prudente (Brazil). Urban Agriculture Magazine 4: 38-39.

Manns, D. 1995. Linalool and cineole type glucosides from Cunila spicata. Phytochemistry 39(5): 1115-1118.

Martins, F. R. 1991. Estrutura de uma Floresta Mesófila. Campinas: UNICAMP.

Moura, C. L. \& Andrade, L. H. C. 2007. Etnobotânica em quintais urbanos nordestinos: um estudo no bairro da Muribeca, Jaboatão dos Guararapes - PE. Revista Brasileira de Biociências 5(supl. 1): 219-221.

Murrieta, R. S. S. 2001. Dialética do sabor: alimentação, ecologia e vida cotidiana em comunidades ribeirinhas da Ilha de Ituqui, Baixo Amazonas, Pará. Revista de Antropologia 44(2): 1-28.

Nair, P. K. R. 1993. An introduction to agroforestry . ICRAF/KLUWER, Academic Publishers.

Niñez, V. K. 1984. Household gardens: theoretical considerations on an old survival strategy. Potatoes in Food Systems Research Series 1: 1-41.

Niñez, V. K.. 1985. Introduction: household gardens and small-scale food production. Food and Nutrition Bulletin 7(3): 1-5.

Padoch, C. \& De Jong, W. 1991. The house gardens of Santa Rosa: diversity and variability in an amazonian agricultural system. Economic Botany 45: 166-75.

Panizza, S. 1982. Emprego medicinal de plantas importadas e sucedâneas que ocorrem no Brasil. Revista de Ciências Farmacêuticas 4: 27-38.

Pilla, M. A.; Amorozo, M. C. M. \& Furlan, A. 2006. Obtenção e uso das plantas medicinais no distrito de Martim Francisco, Município de Mogi-Mirim, SP, Brasil. Acta Botanica Brasilica 20(4): 789-802. 
Rico-Gray, V.; Garcia-Franco, J. G.; Chemas, A. \& Sima, P. 1990 Species, composition, similarity and structure of Maya homegardens in Tixpeual and Tixcacaltuyub, Yucatan, Mexico. Economic Botany 44(4): 470-87.

Santhakumar, V. 2003. Biodiversity in homegardens towards a viable conservation strategy. http://sdnp.delhi.nic.in/nbsap/subthemes/ homegardens.html.

Semedo, R. J. C. G. \& Barbosa, R. I. 2007. Árvores frutíferas nos quintais urbanos de Boa Vista, Roraima, Amazônia brasileira. Acta Amazonica 37(4): 497-504

Siegel, S. 1975. Estatística Não-paramétrica para as Ciências do Comportamento. São Paulo. McGraw-Hill do Brasil.

Silva, S. \& Tassara, H. 2001. Frutas no Brasil. São Paulo. Nobel.

Silva-Almeida, M. F. \& Amorozo, M. C. M. 1998. Medicina popular no distrito de Ferraz - município de Rio Claro-SP. Brazilian Journal of Ecology 2: 36-46.

Soemarwoto, O. 1987. Home gardens: a traditional agroforestry system with a promising future. In: H.A Steppler \& P.K.R. Nair (eds.) Agorofrestry: A Decade of Development. ICRAF,Nairobi, Kenya.
Soemarwoto, O. \& Conway, G. R. 1991. The javanese homegarden. Journal for Farming Systems Research Extension 2(3): 95-117.

Soemarwoto, O.; Soemarwoto, I.; Soekartadiredja, K.E.M. \& Ramlan, A. 1985. The javanese home garden as an integrated agro-ecosystem. Food and Nutrition Bulletin 7(3): 44-47.

Torquebiau, E. 1992. Are tropical agroforestry home gardens sustainable? Agriculture, Ecosystem and Environment 41: 189-207.

Troppmair, H. 1992. Atlas da Qualidade ambiental e de vida de Rio Claro - SP. Rio Claro.

United Nations. 2003. World urbanization prospects: the 2003 revision. http://www.un.org/esa/population/publications/wup2003/ WUP2003Report.pdf

Valle, T. L. 2000. Coleta de germoplasma de plantas cultivadas. In: Amorozo, M. C M.; Ming, L. C. \& Silva, S. P. (Ed.). Métodos de coleta e análise de dados em etnobiologia, etnoecologia e disciplinas correlatas. UNESP

Veiga, J. E. 2003. Cidades imaginárias - o Brasil é menos urbano do que se calcula. Campinas. Editora Autores Associados.

Winklerprins, A. M. G. A. 2002. House-lot gardens in Santarém, Pará, Brazil: Linking rural with urban. Urban Ecosystems 6: 43-65. 
Appendix 1. Species found in urban homegardens in Rio Claro.

\begin{tabular}{|c|c|c|c|}
\hline Species (Record's number) & Common name - English/ Portuguese & Uses & $\mathrm{N}^{\circ}$ houses \\
\hline \multicolumn{4}{|c|}{ Family: Acanthaceae } \\
\hline Asystasia gangetica T.Anders. (Eichemberg, M.T. $\mathrm{n}^{\circ} 283$ ) & Flowering vine/ Flor tipo trepadeira & $\mathrm{O}$ & 1 \\
\hline Crossandra infundibuliformis Nees "Mona wallhead" (Eichemberg, M.T. n 670) & Flower/ Flor & $\mathrm{O}$ & 1 \\
\hline Eranthemum nervosum R.Br. ex. Roem. \& Schult (Eichemberg, M.T. n 626) & Flower/ Flor & $\mathrm{O}$ & 1 \\
\hline Hypoestes sanguinolenta (Van Houtte) Hook. (Eichemberg, M.T. n 309, 427, 571) & Green plant / Folhagem & $\mathrm{O}$ & 3 \\
\hline Justicia brandegeana Wassh.\& Lor.B.Sm. (Eichemberg, M.T. n 266, 440) & Shrimp plant / camarão & $\mathrm{O}$ & 4 \\
\hline Justicia carnea Lindl. (Eichemberg, M.T. n 280) & Flower/ Flor & $\mathrm{O}$ & 1 \\
\hline Pachystachys lutea Nees (Eichemberg, M.T. n² 265, 436) & Golden shrimp plant/Camarão/língua-de-sogra & $\mathrm{O}$ & 3 \\
\hline Ruellia brevifolia (Poh1.) C.Ezcurra (Eichemberg, M.T. n 447) & Flower/ Flor & $\mathrm{O}$ & 1 \\
\hline Sanchezia nobilis Hook. (Eichemberg, M.T. n 294) & Green plant/ Folhagem & $\mathrm{O}$ & 1 \\
\hline Thunbergia mysorensis (Wight) T.Anders ex Bedd (Eichemberg, M.T. ${ }^{\circ}{ }^{449}$ ) & Clock Vine/ Trepadeira sapatinho-de-judia & $\mathrm{O}$ & 1 \\
\hline indet. (Eichemberg, M.T. n 332, 667) & Green plant/ Folhagem & $\mathrm{O}$ & 1 \\
\hline \multicolumn{4}{|c|}{ Family: Amaranthaceae } \\
\hline Alternanthera bettzickiana (Regel) Standl. (Eichemberg, M.T. $\mathrm{n}^{\circ} 421$ ) & Green plant /Folhagem & $\mathrm{O}$ & 1 \\
\hline Alternanthera brasiliana (L.)O. Kuntze (Eichemberg, M.T. $\mathrm{n}^{\circ} 15$ ) & ---/ Penicilina & M & 4 \\
\hline Alternanthera ficoidea (L.) P. Beauv (Eichemberg, M.T. n 471) & ---/ Periquito & $\mathrm{O}$ & 1 \\
\hline Celosia cristata Linn (Eichemberg, M.T. $\mathrm{n}^{\circ} 442$ ) & Bombay purple/ Crista-de-galo & $\mathrm{O}$ & 2 \\
\hline Gomphrena celosioides Mart. (Eichemberg, M.T. n ${ }^{\circ} 551$ ) & Flower/ Flor & $\mathrm{O}$ & 1 \\
\hline Gomphrena globosa Linn (Eichemberg, M.T. $\mathrm{n}^{\circ} 559$ ) & Globe amaranth/ Perpétua & $\mathrm{O}$ & 2 \\
\hline \multicolumn{4}{|c|}{ Family: Amaryllidaceae } \\
\hline Crinum ef powellii Hort. Ex Baker & Crinum/ Açucena & $\mathrm{O}$ & 2 \\
\hline Crinum sp & Amariyllis/ Amarilis & $\mathrm{O}$ & 2 \\
\hline Eucharis grandiflora Planch. \& Linden (Eichemberg, M.T. $n^{\circ} 573$ ) & ---/ Estrela-D’Alva & $\mathrm{O}$ & 3 \\
\hline Hippeastrum reginae (L.)Herb. (Eichemberg, M.T. n 646) & ---/ Açucena & $\mathrm{O}$ & 1 \\
\hline Scadoxus multiflorus (Martyn) Raf. (Eichemberg, M.T. n² 210) & Africa blood lily/ Coroa-do-império & $\mathrm{O}$ & 1 \\
\hline \multicolumn{4}{|c|}{ Family: Anacardiaceae } \\
\hline Anacardium occidentale Linn (Eichemberg, M.T. $\mathrm{n}^{\circ} 10,58,581$ ) & Cashew fruit/ Cajú & $\mathrm{A} / \mathrm{M}$ & 6 \\
\hline Mangifera indica Linn (Eichemberg, M.T. n² 2, 7, 590) & $\begin{array}{l}\text { Mango/*Manga espada/coquinho } \\
\text { /bourbon/Ades/abacaxi }\end{array}$ & A & 14 \\
\hline Spondias purpurea Linn (Eichemberg, M.T. $\mathrm{n}^{\circ} 528$ ) & ---/ Siriguela & A & 1 \\
\hline \multicolumn{4}{|c|}{ Family: Annonaceae } \\
\hline Annona muricata Linn (Eichemberg, M.T. n ${ }^{\circ}$ 527) & Soursop/ Graviola & $\mathrm{A} / \mathrm{M}$ & 1 \\
\hline Annona reticulata Linn (Eichemberg, M.T. n 1, 65, 456) & ---/ fruta-do-conde & $\mathrm{A} / \mathrm{M}$ & 3 \\
\hline Rollinia mucosa (Jacq.)Baill (Eichemberg, M.T. n 105) & ---/ Pinha & A & 6 \\
\hline Rollinia sp (Eichemberg, M.T. n 129) & ---/ Fruta-do-conde & $\mathrm{A} / \mathrm{M}$ & 1 \\
\hline \multicolumn{4}{|c|}{ Family: Apiaceae } \\
\hline Daucus carota Linn & Carrot/ Cenoura & A & 1 \\
\hline Foeniculum vulgare Linn (Eichemberg, M.T. n 24 ) & ---/ Erva-doce & M & 1 \\
\hline Petroselinum sativum Hoffm. (Eichemberg, M.T. $\mathrm{n}^{\circ} 124$ ) & Parsley/Salsa & $\mathrm{A} / \mathrm{M}$ & 9 \\
\hline \multicolumn{4}{|c|}{ Family: Apocynaceae } \\
\hline Allamanda cathartica Linn (Eichemberg, M.T. n 438, 693) & Golden trumpet/ Alamanda & $\mathrm{O}$ & 1 \\
\hline Catharanthus roseus (L.)G.Don (Eichemberg, M.T. n 368, 464, 494) & Madagascar periwinkle/ Beijo/boa-noite & $\mathrm{O}$ & 3 \\
\hline Ervatamia coronaria (Jacq.)Stapf. (Eichemberg, M.T. n³41,470, 539, 627) & ---/ Árvore da flor branca/Jasmim & $\mathrm{O}$ & 4 \\
\hline Nerium oleander Linn (Eichemberg, M.T. n² $245,562,647$ ) & Oleander/ Espirradeira & $\mathrm{O} / \mathrm{M}$ & 3 \\
\hline Trachelospermum jasminoides Lem. (Eichemberg, M.T. n 503) & Star jasmine / Jasmim miúdo & $\mathrm{O}$ & 1 \\
\hline \multicolumn{4}{|c|}{ Family: Aquifoliaceae } \\
\hline Ilex cf aquifolium Linn (Eichemberg, M.T. n 243, 642) & ---/ Azevinho/Espinheira-Santa & M & 1 \\
\hline \multicolumn{4}{|c|}{ Family: Araceae } \\
\hline Aglaonema commutatum Schott. (Eichemberg, M.T. $\mathrm{n}^{\circ} 510$ ) & Green plant /Folhagem & $\mathrm{O}$ & 1 \\
\hline Aglaonema pseudo-bracteatum Hort. (Eichemberg, M.T. n 146, 346, 425, 449, 538) & ---/ Comigo ninguém pode & $\mathrm{O}$ & 5 \\
\hline Alocasia cuprea K.Koch (Eichemberg, M.T. n 196) & ---/ Costela-de-Adão & $\mathrm{O}$ & 1 \\
\hline Alocasia macrorhiza Schott (Eichemberg, M.T. n 130, 385) & Giant taro / Taioba/orelha-de-elefante & $\mathrm{M} / \mathrm{A}$ & 3 \\
\hline Anthurium andraeanum Linden (Eichemberg, M.T. n 163, 194, 430) & Tailflower/ Antúrio & $\mathrm{O}$ & 5 \\
\hline Anthurium froebelii Hort. (Eichemberg, M.T. $n^{\circ} 256,267,282,362$ ) & Tailflower/ Antúrio & $\mathrm{O}$ & 11 \\
\hline Caladium $x$ hortulanum Birdsey (Eichemberg, M.T. n 161, 212) & ---/ Coração-de-boi & $\mathrm{O}$ & 3 \\
\hline cf Philodendron martianum Engl. (Eichemberg, M.T. $\mathrm{n}^{\circ}$ 406) & Green plant/Folhagem & $\mathrm{O}$ & 1 \\
\hline
\end{tabular}


Appendix 1 (Continuação).

\begin{tabular}{|c|c|c|c|}
\hline Species (Record's number) & Common name - English/ Portuguese & Uses & $\mathrm{N}^{\mathrm{o}}$ houses \\
\hline Dieffenbachia amoena Bull. (Eichemberg, M.T. $n^{\circ}$ 269, 313, 431, 433, 445, 509, 517) & Dumb Cane / Comigo-ninguém-pode & Out/O & 5 \\
\hline Monstera adansonii Schott (Eichemberg, M.T. n² 270, 344) & Green plant/ Folhagem/ Guembê & $\mathrm{O}$ & 2 \\
\hline Monstera deliciosa Liebm. & Green plant/ Folhagem & $\mathrm{O}$ & 1 \\
\hline Philodendron bipinnatifidum Schott ex Endl. (Eichemberg, M.T. n ${ }^{\circ} 19$ ) & ---/ Banana-de-macaco/Guembé & $\mathrm{M} / \mathrm{O}$ & 1 \\
\hline Philodendron cf imbe Schott. (Eichemberg, M.T. $\mathrm{n}^{\circ} 172,211$ ) & Green plant / Folhagem & $\mathrm{O} /$ Out & 2 \\
\hline Philodendron selloum C.Koch (Eichemberg, M.T. $\mathrm{n}^{\circ} 154$ ) & ---/ Guembê & $\mathrm{O} / \mathrm{M}$ & 1 \\
\hline Scindapsus aureus Engl. (Eichemberg, M.T. n ${ }^{\circ} 157,363,386,502,512$ ) & ---/ Jibóia/Costela-de-Adão & $\mathrm{O}$ & 5 \\
\hline Spathiphyllum wallisi Regel (Eichemberg, M.T. $\mathrm{n}^{\circ} 217,392,673$ ) & Peace lily/ Lírio da paz & $\mathrm{O}$ & 7 \\
\hline $\begin{array}{l}\text { Syngonium angustatum Schott (Eichemberg, M.T. } n^{\circ} 158,171,215,216,271,327 \text {, } \\
350,424,428,461,492 \text { ) }\end{array}$ & ---/ Orelha-de-burro/cabeça-de-cavalo & $\mathrm{O}$ & 9 \\
\hline Zantedeschia aethiopica Spreng. & Calla lily/ Copo de leite & $\mathrm{O}$ & 1 \\
\hline \multicolumn{4}{|c|}{ Family: Araliaceae } \\
\hline Hedera helix Linn (Eichemberg, M.T. $\mathrm{n}^{\circ}$ 514) & Vine/ Trepadeira & $\mathrm{O}$ & 1 \\
\hline Polyscias balfouriana L.H.Bailey (Eichemberg, M.T. $\mathrm{n}^{\circ} 426$ ) & Flower/green plant / Flor/Folhagem & $\mathrm{O}$ & 1 \\
\hline Polyscias fruticosa Harms (Eichemberg, M.T. $\mathrm{n}^{\circ} 177$ ) & Ming aralia / Árvore-da-felicidade/Dinheiro & $\mathrm{O} /$ Out & 7 \\
\hline Polyscias guilfoylei L.H.Bailey (Eichemberg, M.T. n $^{\circ} 46$ ) & Ming aralia/ Árvore-da-felicidade & $\mathrm{O}$ & 2 \\
\hline Schefflera arboricola (Hayata) Merr. (Eichemberg, M.T. $n^{\circ} 168,380,513$ ) & ---/ Chefléria & $\mathrm{O}$ & 3 \\
\hline \multicolumn{4}{|c|}{ Family: Arecaceae } \\
\hline Coccothrinax argentata (N.J.Jacquim) L.H.Bailey & Palm/ Palmeira & $\mathrm{O}$ & 1 \\
\hline Cocos nucifera Linn & Coconut/ Côco & A & 1 \\
\hline Dypsis lutescens (H.Wendl.) Beentje \& J.Dransf. & Bamboo/ Bambú & $\mathrm{O}$ & 5 \\
\hline Rhapis excelsa (Thunberg) Henry ex. Rehder (Eichemberg, M.T. n $^{\circ} 289$ ) & Palm/ Palmeira & $\mathrm{O}$ & 1 \\
\hline Indet. & Palm/ Palmeira & A & 1 \\
\hline \multicolumn{4}{|c|}{ Family: Asclepiadaceae } \\
\hline Hoya carnosa R.Br. (Eichemberg, M.T. n 272,429 ) & Wax flower or porcelain flower/ Flor-de-cêra & $\mathrm{O}$ & 2 \\
\hline Stapelia hirsuta Linn (Eichemberg, M.T. $\mathrm{n}^{\circ} 628$ ) & Cactus & $\mathrm{O}$ & 3 \\
\hline Stephanotis floribunda Brongn. (Eichemberg, M.T. $\mathrm{n}^{\circ} 268$ ) & ---/ Estefanorte & $\mathrm{O}$ & 3 \\
\hline \multicolumn{4}{|c|}{ Family: Aspleniaceae } \\
\hline Asplenium nidus Linn & ---/ Esplênio & $\mathrm{O}$ & 1 \\
\hline \multicolumn{4}{|c|}{ Family: Asteraceae } \\
\hline Achillea millefolium Linn (Eichemberg, M.T. $\left.\mathrm{n}^{\circ} 374\right)$ & ---/ Anador & M & 1 \\
\hline Ageratum conyzoides Linn (Eichemberg, M.T. $\mathrm{n}^{\circ} 553$ ) & ---/ Mentrasto & M & 1 \\
\hline Anthemis nobilis Linn (Eichemberg, M.T. $\mathrm{n}^{\circ} 35$ ) & ---/ Macelinha galega & M & 1 \\
\hline Artemisia absinthium Linn (Eichemberg, M.T. $\mathrm{n}^{\circ}$ 37) & ---/ Losna & M & 3 \\
\hline Artemisia camphorata Vill. (Eichemberg, M.T. $\mathrm{n}^{\circ} 66,125$ ) & ---/ Cânfora & M & 3 \\
\hline Baccharis trimera (Less) DC. (Eichemberg, M.T. n 34, 593) & ---/ Carqueja & M & 3 \\
\hline Bidens pilosa Linn (Eichemberg, M.T. $\mathrm{n}^{\circ}$ 676) & ---/ Picão & M & 1 \\
\hline Bidens sulphurea Sch. Bip. (Eichemberg, M.T. n 688 ) & ---/ Flor-do-campo & $\mathrm{O}$ & 1 \\
\hline Callistephus chinensis Nees (Eichemberg, M.T. $\mathrm{n}^{\circ}$ 378) & ---/ Rainha-de-margarida & $\mathrm{O}$ & 1 \\
\hline Chrysanthemum leucanthemum Linn (Eichemberg, M.T. $\mathrm{n}^{\circ} 481,505$ ) & ---/ Margarida/Olga & $\mathrm{O}$ & 3 \\
\hline Chrysanthemum parthenium Bernh. & ---/ Artemija & $\mathrm{O} / \mathrm{M}$ & 1 \\
\hline Cichorium intybus Linn (Eichemberg, M.T. $\mathrm{n}^{\circ} 586$ ) & ---/ Almeirão & A & 5 \\
\hline Dahlia pinnata Cav. (Eichemberg, M.T. n ${ }^{\circ 63)}$ & ---/ Dália & $\mathrm{O}$ & 2 \\
\hline Dendranthema grandiflorum (Ramat.) Kitam. (Eichemberg, M.T. n 192, 226, 358) & ---/Artemísia/Bom-Senhor/crisantema & $\mathrm{M} / \mathrm{O}$ & 6 \\
\hline Emilia sonchifolia (L.)D.C. (Eichemberg, M.T. $\mathrm{n}^{\circ}$ 684) & $---/$ Serraia & $\mathrm{A} / \mathrm{M}$ & 1 \\
\hline Gerbera jamesoni Bolus (Eichemberg, M.T. $\mathrm{n}^{\circ} 377$ ) & ---/ Gerbra & $\mathrm{O}$ & 1 \\
\hline Helichrysum bracteatum Andr. & ---/ Sempre-viva & $\mathrm{O}$ & 2 \\
\hline Lactuca sativa Linn & Lettuce/ Alface & A & 1 \\
\hline Mikania glomerata Spreng. (Eichemberg, M.T. $\mathrm{n}^{\circ} 621$ ) & ---/ Guaco & M & 1 \\
\hline Mikania cordifolia (L.f.) Willd. (Eichemberg, M.T. n 36, 630 ) & $---/$ Guaco & M & 4 \\
\hline Porophyllum ruderale (Jacq.) Coss. (Eichemberg, M.T. n 93, 678) & ---/ Arnica & M & 3 \\
\hline Tagetes erecta Linn (Eichemberg, M.T. $\mathrm{n}^{\circ} 312$ ) & ---/ Cravo-de-defunto & $\mathrm{O} / \mathrm{M}$ & 1 \\
\hline Tithonia diversifolia A.Gray (Eichemberg, M.T. $\mathrm{n}^{\circ}$ 142) & ---/ Mão-de-Deus & $\mathrm{O}$ & 1 \\
\hline Vernonia condensata Baker (Eichemberg, M.T. $\mathrm{n}^{\circ}$ 137, 189, 639) & ---/ Estomalina & M & 2 \\
\hline Zinnia elegans Jacq. (Eichemberg, M.T. $\mathrm{n}^{\circ}$ 387) & ---/ Capitão & $\mathrm{O}$ & 1 \\
\hline \multicolumn{4}{|c|}{ Family: Balsaminaceae } \\
\hline Impatiens balsamina Linn (Eichemberg, M.T. $\mathrm{n}^{\circ}$ 555) & ---/ Beijo & $\mathrm{O}$ & 2 \\
\hline
\end{tabular}


Appendix 1 (Continuação).

\begin{tabular}{|c|c|c|c|}
\hline Species (Record's number) & Common name - English/ Portuguese & Uses & $\mathrm{N}^{\mathrm{o}}$ houses \\
\hline $\begin{array}{l}\text { Impatiens walleriana Hook.f. } \\
\left.\text { Impatiens walleriana Hook.f."Nana" (Eichemberg, M.T. } n^{\circ} 159,552,602\right)\end{array}$ & $\begin{array}{l}\text {---/ Beijo/Maria sem vergonha } \\
\text { Beijo-alemão }\end{array}$ & $\mathrm{O}$ & 6 \\
\hline \multicolumn{4}{|c|}{ Family: Begoniaceae } \\
\hline Begonia aconitifolia A. DC. (Eichemberg, M.T. $\mathrm{n}^{\circ} 273,329,521$ ) & ---/ Begônia /alfinete-de-moça & $\mathrm{O}$ & 3 \\
\hline Begonia boveri Ziesenh. "Nigramarga" (Eichemberg, M.T. ${ }^{\circ}{ }^{\circ} 72$ ) & Begonia & $\mathrm{O}$ & 1 \\
\hline Begonia cf ulmifolia Willd. (Eichemberg, M.T. n 288) & Begonia & $\mathrm{O}$ & 1 \\
\hline Begonia coccinea Hook. (Eichemberg, M.T. $\mathrm{n}^{\circ} 278$ ) & Begonia & $\mathrm{O}$ & 1 \\
\hline Begonia cucullata Willd. (Eichemberg, M.T. $\mathrm{n}^{\circ} 224$ ) & ---/ Azedinha & $\mathrm{O}$ & 1 \\
\hline Begonia elatior Hort. ex Steud. (Eichemberg, M.T. $\mathrm{n}^{\circ} 472$ ) & Green plant/ Folhagem & $\mathrm{O}$ & 1 \\
\hline Begonia manicata Cels. ex Vis. (Eichemberg, M.T. n 173, 315) & Begonia /green plant/ Folhagem & $\mathrm{O}$ & 2 \\
\hline Begonia sp (Eichemberg, M.T. n 179, 281, 366, 530, 645) & ---/ Begônia & $\mathrm{O}$ & 5 \\
\hline \multicolumn{4}{|c|}{ Family: Bignoniaceae } \\
\hline Podranea ricasoliana Sprague (Eichemberg, M.T. $\mathrm{n}^{\circ} 478$ ) & Vine/ sete-léguas & $\mathrm{O}$ & 1 \\
\hline Pyrostegia venusta Miers (Eichemberg, M.T. $\mathrm{n}^{\circ}$ 525) & ---/ Flor-de-São João & $\mathrm{O}$ & 1 \\
\hline Tabebuia sp (Eichemberg, M.T. $\mathrm{n}^{\circ}$ 648) & ---/ Ipê-amarelo & $\mathrm{O}$ & 1 \\
\hline Indet. (Eichemberg, M.T. $\left.n^{\circ} 257\right)$ & ---/ Ipê-roxo & $\mathrm{O}$ & 1 \\
\hline \multicolumn{4}{|c|}{ Family: Boraginaceae } \\
\hline Cordia ecalyculata Vell. (Eichemberg, M.T. $\mathrm{n}^{\circ} 72,671$ ) & ---/ Café-de-bugre & M & 1 \\
\hline Symphytum officinale Linn (Eichemberg, M.T. $\mathrm{n}^{\circ} 39,466$ ) & Comfrey/ Confrei & M & 2 \\
\hline \multicolumn{4}{|c|}{ Family: Brassicaceae } \\
\hline Brassica oleracea Linn v. italica (Eichemberg, M.T. $\mathrm{n}^{\circ} 620$ ) & Brocoli/Brócolis & A & 1 \\
\hline Brassica oleracea Linn v. acephala (Eichemberg, M.T. $n^{\circ} 594$ ) & Cabbage/ Couve & $\mathrm{A} / \mathrm{M}$ & 11 \\
\hline Eruca sativa Mill. (Eichemberg, M.T. $\mathrm{n}^{\circ}$ 689) & Arugula/Rúcula & A & 2 \\
\hline Sinapsis arvensis Linn (Eichemberg, M.T. $n^{\circ} 231,687$ ) & Mustadr/ Mostarda & A & 4 \\
\hline \multicolumn{4}{|c|}{ Family: Bromeliaceae } \\
\hline Ananas ananassoides (Baker) L.B.Smith (Eichemberg, M.T. $\mathrm{n}^{\circ}$ 92) & Ornamental pineapple & A & 3 \\
\hline Ananas comosus (L.) Merr. & Pineapple/Abacaxi & $\mathrm{O}$ & 6 \\
\hline Bromelia cf balansae $\mathrm{Mez}$ & Pineapple/Abacaxi & $\mathrm{O}$ & 1 \\
\hline Guzmania ligulata $\mathrm{Mez}$ & ---/ Bromelia & $\mathrm{O}$ & 1 \\
\hline \multicolumn{4}{|c|}{ Family: Buxaceae } \\
\hline Buxus sempervirens Linn (Eichemberg, M.T. $\mathrm{n}^{\circ}$ 533) & ---/ Buchinha & $\mathrm{O}$ & 1 \\
\hline \multicolumn{4}{|c|}{ Family: Cactaceae } \\
\hline Cereus cf jamacaru DC. & ---/ Cactus & $\mathrm{O}$ & 1 \\
\hline Hylocereus undatus Britton \& Rose & ---/ Cactus & $\mathrm{O}$ & 1 \\
\hline Rhipsalis baccifera (Mill.) Stearn (Eichemberg, M.T. $\mathrm{n}^{\circ} 18,164$ ) & ---/ Cactus/Flor-da-miséria & $\mathrm{O}$ & 7 \\
\hline Rhipsalis cf oblonga Loefgr. & $---/$ Cactus & $\mathrm{O}$ & 2 \\
\hline Schlumbergera truncata (Haw.) Moran (Eichemberg, M.T. $n^{\circ} 201,390$ ) & Holiday cactus/ Flor-de-maio & $\mathrm{O}$ & 8 \\
\hline indet1 & ---/ Cactus & $\mathrm{O}$ & 2 \\
\hline indet2 & ---/ Cactus & $\mathrm{O}$ & 2 \\
\hline indet3 & ---/ Cactus 5 & $\mathrm{O}$ & 1 \\
\hline indet4 & ---/ Cactus 6 & $\mathrm{O}$ & 1 \\
\hline indet5 & $---/$ Cactus 8 & $\mathrm{O}$ & 1 \\
\hline \multicolumn{4}{|c|}{ Family: Campanulaceae } \\
\hline Isotoma longiflora J.Presl (Eichemberg, M.T. $\mathrm{n}^{\circ} 473$ ) & ---/ Folha espinhuda & $\mathrm{O}$ & 1 \\
\hline \multicolumn{4}{|c|}{ Family: Cannaceae } \\
\hline Canna denudata Roscoe (Eichemberg, M.T. $\mathrm{n}^{\circ} 219,482$ ) & Coloral,green plant/ Folhagem & $\mathrm{A} / \mathrm{O}$ & 2 \\
\hline Canna $\mathrm{x}$ generalis L.H.Bailey & ---/ Lírio/Palma-de-São José & $\mathrm{O}$ & 2 \\
\hline \multicolumn{4}{|c|}{ Family: Caprifoliaceae } \\
\hline Lonicera japonica Thunb. (Eichemberg, M.T. $\mathrm{n}^{\circ} 252$ ) & ---/ Trepadeira madressilva & $\mathrm{O}$ & 1 \\
\hline \multicolumn{4}{|c|}{ Family: Caricaceae } \\
\hline Carica papaya Linn & $\begin{array}{l}\text { *Mamão/Mamão amarelo/Mamão bola/Mamão } \\
\text { papaya }\end{array}$ & $\mathrm{A} / \mathrm{M}$ & 16 \\
\hline \multicolumn{4}{|c|}{ Family: Caryophyllaceae } \\
\hline Dianthus caryophyllus Linn (Eichemberg, M.T. $\mathrm{n}^{\circ}$ 484) & Carnation/Cravinho & $\mathrm{O}$ & 1 \\
\hline \multicolumn{4}{|c|}{ Family: Celastraceae } \\
\hline Euonymus japonica Linn f. (Eichemberg, M.T. $\mathrm{n}^{\circ}$ 19) & Shrub/ Arbusto & $\mathrm{O}$ & 1 \\
\hline \multicolumn{4}{|c|}{ Family: Chenopodiaceae } \\
\hline Chenopodium ambrosioides Linn (Eichemberg, M.T. $\mathrm{n}^{\circ}$ 38) & ---/ Erva-de-Santa Maria & M & 6 \\
\hline Spinacia oleracea Linn (Eichemberg, M.T. n ${ }^{\circ} 589$ ) & Spinach/ Espinafre & A & 1 \\
\hline
\end{tabular}


Appendix 1 (Continuação).

\begin{tabular}{|c|c|c|c|}
\hline Species (Record's number) & Common name - English/ Portuguese & Uses & $\mathrm{N}^{\circ}$ houses \\
\hline \multicolumn{4}{|c|}{ Family: Commelinaceae } \\
\hline Commelina cf erecta Linn (Eichemberg, M.T. n 548) & ---/ Flor roxa & $\mathrm{O}$ & 1 \\
\hline Dichorisandra thyrsiflora J.C.Mikan (Eichemberg, M.T. $\mathrm{n}^{\circ}$ 441) & Green plant/ Folhagem & $\mathrm{O}$ & 2 \\
\hline \multicolumn{4}{|c|}{ Family: Convolvulaceae } \\
\hline Evolvulus glomeratus Nees \& Mart. (Eichemberg, M.T. n 342, 410) & ---/ Flor azul/florzinha miúda & $\mathrm{O}$ & 2 \\
\hline \multicolumn{4}{|c|}{ Family: Costaceae } \\
\hline Costus spiralis Roscoe (Eichemberg, M.T. $n^{\circ}$ 85, 261, 264, 275) & ---/ Cana-da-Índia/cana-do-brejo & $\mathrm{O} / \mathrm{M}$ & 7 \\
\hline \multicolumn{4}{|c|}{ Family: Crassulaceae } \\
\hline Bryophillum calycinum Salisb. (Eichemberg, M.T. n 322) & ---/ Mão-de-Deus & $\mathrm{O}$ & 1 \\
\hline Kalanchoe blossfeldiana Poelln. (Eichemberg, M.T. n 199, 301) & ---/ Balalaica/flor-dos-pais & $\mathrm{O}$ & 5 \\
\hline Kalanchoe fedtschenkoi Hamet-Ahti \& H.Perrier & ---/ Flor-dos-pais/flor-do-Ceará & $\mathrm{O}$ & 2 \\
\hline Kalanchoe gastonis-bonnieri Hamet-Ahti \& H.Perrier (Eichemberg, M.T. n 33,578 ) & ---/ Remédio-para-câncer/Green plant/ Folhagem & M & 3 \\
\hline Sedum dendroideum Moc. \& Sessé ex DC. (Eichemberg, M.T. n 314) & ---/ Bálsamo & M & 7 \\
\hline Sedum morganianum Walth. (Eichemberg, M.T. n 497) & ---/ Dedo-de-moça & $\mathrm{O} / \mathrm{M}$ & 1 \\
\hline Sedum spectabile Bor (Eichemberg, M.T. n 255) & Green plant/ Folhagem & $\mathrm{O}$ & 1 \\
\hline Indet. (Eichemberg, M.T. n 394) & Green plant/ Folhagem & $\mathrm{O}$ & 1 \\
\hline Indet. (Eichemberg, M.T. n³95) & Green plant/ Folhagem & $\mathrm{O}$ & 1 \\
\hline \multicolumn{4}{|c|}{ Family: Cucurbitaceae } \\
\hline Cucumis melo Linn & Melon/ Melão & A & 1 \\
\hline Cucurbita maxima Duch. & ---/ Moranga & A & 1 \\
\hline Cucurbita moschata Duch. (Eichemberg, M.T. $\mathrm{n}^{\circ} 61$ ) & Squash/Abóbora & A & 3 \\
\hline Luffa cylindrica (L..) Roem. (Eichemberg, M.T. n 110 ) & Loofah sponge gourd/ Bucha vegetal & Outros & 1 \\
\hline Sechium edule (Jacq.)Sw. (Eichemberg, M.T. n 49) & Chayote/ Chuchu/Machuchu & A & 2 \\
\hline \multicolumn{4}{|c|}{ Family: Cupressaceae } \\
\hline Chamaecyparis obtusa Sieb. \& Zucc. (Eichemberg, M.T. n 653) & ---/ Pinheiro/cipreste & $\mathrm{O}$ & 1 \\
\hline \multicolumn{4}{|c|}{ Family: Cycadaceae } \\
\hline Cycas circinalis Roxb. & Cica/palmeira & $\mathrm{O}$ & 3 \\
\hline Cycas revoluta Thunb. & ---/ Coqueiro & $\mathrm{O}$ & 1 \\
\hline \multicolumn{4}{|c|}{ Family: Cyclanthaceae } \\
\hline Carludovica palmata Ruiz \& Pav. (Eichemberg, M.T. n 393) & ---/ Coqueiro & $\mathrm{O}$ & 2 \\
\hline \multicolumn{4}{|c|}{ Family: Davalliaceae } \\
\hline Davallia fijiensis Hook (Eichemberg, M.T. n² 203, 235, 384) & Davallia fern/ Renda-portuguesa & $\mathrm{O}$ & 11 \\
\hline Nephrolepis biserrata (Sw) Schott. (Eichemberg, M.T. n 532,566 ) & Fern/ Samambaia & $\mathrm{O}$ & 2 \\
\hline Nephrolepis exaltata Schott. (Eichemberg, M.T. n 401,567 ) & Fern/ Samambaia & $\mathrm{O}$ & 4 \\
\hline Nephrolepis pectinata (Willd.) Schott (Eichemberg, M.T. n²06, 616) & Fern/ Samambaia & $\mathrm{O}$ & 1 \\
\hline Nephrolepis sp1 & Fern/ Samambaia & $\mathrm{O}$ & 1 \\
\hline Nephrolepis sp2 & Fern/ Samambaia & $\mathrm{O}$ & 1 \\
\hline Nephrolepis sp3 & Fern/ Samambaia & $\mathrm{O}$ & 1 \\
\hline Nephrolepis sp4 (Eichemberg, M.T. $n^{\circ} 486$ ) & Fern / Samambaia & $\mathrm{O}$ & 1 \\
\hline Nephrolepis sp5 (Eichemberg, M.T. n 32, 364) & Fern / Samambaia paulistinha & $\mathrm{O} / \mathrm{M}$ & 3 \\
\hline Nephrolepis sp6 (Eichemberg, M.T. n 169) & Fern / Samambaia-de-metro & $\mathrm{O}$ & 1 \\
\hline Nephrolepis sp7 (Eichemberg, M.T. n 365) & Fern / Samambaia saia-de-baiana & $\mathrm{O}$ & 1 \\
\hline Nephrolepis sp8 (Eichemberg, M.T. n 204) & Fern / Samambaia cabelo-de-anjo & $\mathrm{O}$ & 3 \\
\hline Nephrolepis sp9 (Eichemberg, M.T. $\left.n^{\circ} 205\right)$ & Fern / Samambaia/samambaia-cabeluda & $\mathrm{O}$ & 3 \\
\hline \multicolumn{4}{|c|}{ Family: Dryopteridaceae } \\
\hline Rumohra adiantiformis (F) Ching (Eichemberg, M.T. $\mathrm{n}^{\circ} 160$ ) & Fern/ Samambaia & $\mathrm{O}$ & 2 \\
\hline \multicolumn{4}{|c|}{ Family: Ebenaceae } \\
\hline Diospyrus kaki Linn (Eichemberg, M.T. n 82) & Persimmon/ Caqui & A & 5 \\
\hline \multicolumn{4}{|c|}{ Family: Ericaceae } \\
\hline Rhododendron simsii Planch. (Eichemberg, M.T. n 198, 308) & Azalia/ Azaléia & $\mathrm{O}$ & 9 \\
\hline \multicolumn{4}{|c|}{ Family: Euphorbiaceae } \\
\hline Acalypha reptans Sw. (Eichemberg, M.T. n³82) & ---/ Rabo-de-gato & $\mathrm{O}$ & 2 \\
\hline Acalypha wilkesiana Müll.Arg. (Eichemberg, M.T. n 432, 518) & Tree/green plant / Folhagem & $\mathrm{O}$ & 3 \\
\hline Breynia nivosa Small (Eichemberg, M.T. n²27, 522) & Green plant / Folhagem & $\mathrm{O}$ & 2 \\
\hline Codiaeum variegatum Blume (Eichemberg, M.T. n 147, 337) & Green plant/ Folhagem & $\mathrm{O}$ & 2 \\
\hline Euphorbia milii Des Moul. ex Boiss. "Milii" & ---/ Coroa-de-Cristo & $\mathrm{O} / \mathrm{M}$ & 1 \\
\hline Euphorbia pulcherrima Willd.ex Klotzsch (Eichemberg, M.T. n 144, 223) & ---/ Flor-de-maio/papagaio/bico-de-papagaio & $\mathrm{O}$ & 5 \\
\hline
\end{tabular}


Appendix 1 (Continuação).

\begin{tabular}{l}
\hline Species (Record's number) \\
\hline Jatropha gossypiifolia Linn (Eichemberg, M.T. $\left.\mathrm{n}^{\circ} 114,680\right)$ \\
Manihot esculenta Crantz (Eichemberg, M.T. $\mathrm{n}^{\circ}$ 608) \\
Pedilanthus tithymaloides Poit. (Eichemberg, M.T. $\mathrm{n}^{\circ}$ 408, 632) \\
Phyllanthus tenellus Roxb. (Eichemberg, M.T. $\mathrm{n}^{\circ}$ 190, 604) \\
Ricinus communis Linn \\
Indet. (Eichemberg, M.T. $\mathrm{n}^{\circ}$ 651)
\end{tabular}

Pelargonium hortorum L.H.Bailey (Eichemberg, M.T. n²18)

Family: Geraniaceae

Common name - En
/ Pinhão
Mandioca/amarela/ bran
reen plant / Folhagem
/ Quebra-pedra
/ Mamona
/ Bálsamo branco

Geranium/ Gerânio

Family: Gesneriaceae

Nematanthus wettsteinii (Fritsch) H.E.Moore (Eichemberg, M.T. n 151, 413) ---/ Flor vermelha 7

Saintpaulia ionantha H. Wendl. (Eichemberg, M.T. n²51, 306)

Violet/ Violeta africana/violeta

Family: Heliconiaceae

Heliconia hirsuta Linn. (Eichemberg, M.T. n²76)

Heliconia rostrata Ruiz \& Pav. (Eichemberg, M.T. n²84)

Belamcanda chinensis DC.

Gladiolus hortulanus L.H.Bailey

Neomarica caerulea Sprague

Neomarica candida Sprague

Lavandula officinalis Chaix \& Kitt. (Eichemberg, M.T. n $\left.{ }^{\circ} 25\right)$

Leonotis nepetaefolia (L.) R.Br. (Eichemberg, M.T. n 596)

Leonurus japonicus Hoult (Eichemberg, M.T. n 126, 691)

Melissa officinalis Linn (Eichemberg, M.T. $\mathrm{n}^{\circ} 321$ )

Mentha citrata Ehrh. (Eichemberg, M.T. n 654)

Mentha pulegium Linn (Eichemberg, M.T. n 70, 121, 323)

Mentha sp1 (Eichemberg, M.T. n 31, 69, 75)

Mentha $\mathrm{cf}$ arvensis Linn (Eichemberg, M.T. $\mathrm{n}^{\circ} 477,601$ )

Mentha sp2 (Eichemberg, M.T. n 356)

Ocimum basilicum Linn (Eichemberg, M.T. $\mathrm{n}^{\circ} 48,540$ )

Ocimum gratissimum Linn (Eichemberg, M.T. $\mathrm{n}^{\circ} 29,120,230$ )

Ocimum selloi Benth. (Eichemberg, M.T. n 27, 56)

Ocimum sp1 (Eichemberg, M.T. n 41, 117)

Ocimum sp2 (Eichemberg, M.T. n 55, 187)

Origanum majorana Linn (Eichemberg, M.T. $\left.\mathrm{n}^{\circ} 74,122,355\right)$

Origanum vulgare Linn (Eichemberg, M.T. $n^{\circ} 123$ )

Plectranthus amboinicus (Lour.) Spreng. (Eichemberg, M.T. $\mathrm{n}^{\circ} 20,592$ )

Plectranthus barbatus Andrews (Eichemberg, M.T. n 6, 84, 113 )

Plectranthus neochilus Schlechter (Eichemberg, M.T. n 30,83)

Plectranthus nummularius Briq. (Eichemberg, M.T. $\mathrm{n}^{\circ} 148$ )

Rosmarinus officinalis Linn (Eichemberg, M.T. $\mathrm{n}^{\circ} 28,68$ )

Salvia officinalis Linn (Eichemberg, M.T. $n^{\circ} 26$ )

Salvia splendens Ker Gawl. (Eichemberg, M.T. $\mathrm{n}^{\circ}$ 247)

Satureja sp (Eichemberg, M.T. n 42)

Solenostemon scutellarioides (L.)Codd. (Eichemberg, M.T. $n^{\circ} 338$ )

Solenostemon sp (Eichemberg, M.T. n 465)

Tetradenia riparia (Hochst.) Codd. (Eichemberg, M.T. n 143, 327)

Laurus nobilis Linn (Eichemberg, M.T. $\mathrm{n}^{\circ} 53,607$ )

Persea americana Mill. (Eichemberg, M.T. n 47, 610)

Leea rubra Blume (Eichemberg, M.T. n 519)

Cassia sp (Eichemberg, M.T. n 339)

Bauhinia forficata Link (Eichemberg, M.T. $n^{\circ} 88$ )
Green plant/ Folhagem
Green plant/bananeira-ornamental/ Folhagem

Family: Iridaceae

$$
\begin{aligned}
& \text {---/ Palma } \\
& \text {---/ Palma } \\
& \text {---/ Íris } \\
& \text {---/ Íris }
\end{aligned}
$$

Family: Lamiaceae

---/ Cânfora
---/ Rubim
---/ Rubi
Balm mint/Cidreira-em-folha
---/ Solevante
Pennyroyal/Poejo
Peppermint/Hortelã
Spearmint/ Hortelã/Menta
Pennyroyal/Poejo
Basil/Manjericão
---/ Alfavacão
---/ Atroverã
---/ Alfavaca

Italian basil/ Manjericão-da-Itália

Marjoram/Manjerona

Oregano/ Orégano

Northern mint/ Hortelã-do-Norte

---/ Boldo

Chilean boldo/ Boldo-do-Chile

---/ Dinheiro-em-penca

Rosemary/Alecrim

Sage/ Sálvia

Sangue-de-Adão

---/ Siguréia

Green plant/ Folhagem

Green plant/ Folhagem

---/ Incenso

Family: Lauraceae

Bay leaf/ Louro

Avocado/ Abacate

Family: Leeaceae

---/ Planta de flor vermelha

Family: Leguminosae-Caesalpinioideae

$$
\text { ----/ Cássia }
$$

Uses

$\mathrm{N}^{\mathrm{o}}$ houses

A

$\mathrm{A} / \mathrm{M} \quad 10$

10

O

M 4

O 1

O

M

O 8

$\begin{array}{ll}\mathrm{O} & 2 \\ \mathrm{O} & 7\end{array}$

$\begin{array}{ll}\mathrm{O} & 1 \\ \mathrm{O} & 1\end{array}$

1

O 1

O 1

O 1

M 1

M 1

M 1

M 2

M 1

M 6

M 10

A/M 2

M 1

A 8

M 4

M 4

A 3

A 3

A 5

A 2

M 1

M 9

M 2

O 2

$\mathrm{A} / \mathrm{M} / \mathrm{Ou} \quad 8$

$\mathrm{A} / \mathrm{M} \quad 1$

Outros 1

A 1

O 3

O 1

Outros 5

A/M 7

A 4

O 1

$\begin{array}{ll}\mathrm{O} & 1 \\ \mathrm{M} & 1\end{array}$

Family: Leguminosae-Mimosoideae 
Appendix 1 (Continuação).

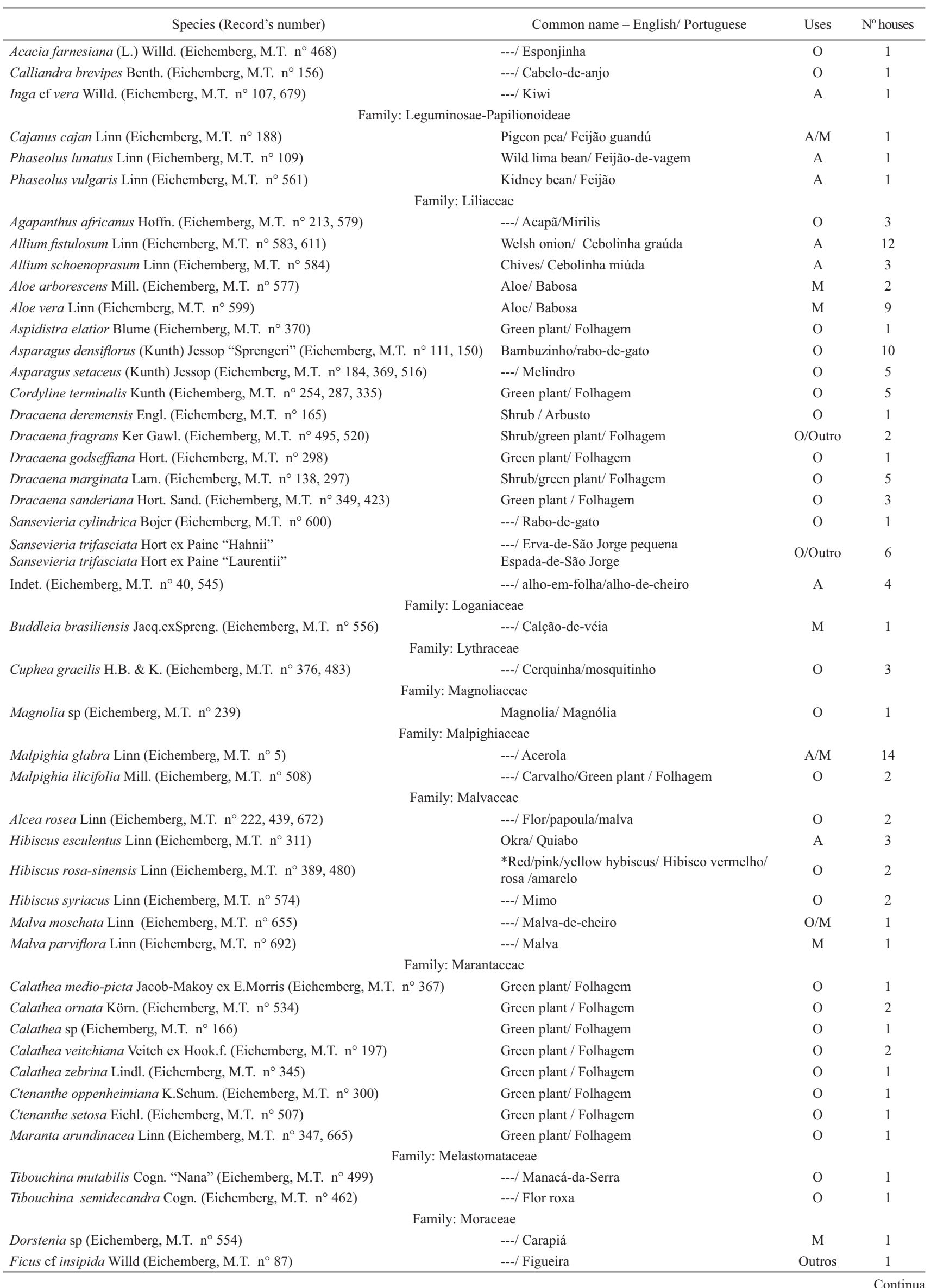


Appendix 1 (Continuação).

\begin{tabular}{|c|c|c|c|}
\hline Species (Record's number) & Common name - English/ Portuguese & Uses & $\mathrm{N}^{\mathrm{o}}$ houses \\
\hline Ficus benjamina Linn (Eichemberg, M.T. n 354) & Green plant/ Folhagem & $\mathrm{O}$ & 1 \\
\hline Ficus carica Linn (Eichemberg, M.T. $n^{\circ} 43$ ) & ---/ Figo miúdo & $\mathrm{A} / \mathrm{M}$ & 8 \\
\hline Ficus pumila Linn & ---/ Unha-de-gato & $\mathrm{O}$ & 1 \\
\hline Morus nigra Linn (Eichemberg, M.T. $n^{\circ} 50,116$ ) & Mulberry/ Amora & $\mathrm{A} / \mathrm{M}$ & 2 \\
\hline Indet. (Eichemberg, M.T. n 685 ) & ---/ Fruta-pão & A & 1 \\
\hline \multicolumn{4}{|c|}{ Family: Musaceae } \\
\hline Musa sapientum Linn & $\begin{array}{l}\text { *Banana figo/maçã/ouro/prata/ } \\
\text { São Domingos }\end{array}$ & A & 4 \\
\hline Musa cavendishii Lamb. Ex Paxton & *Banana nanica/nanicão & A & 4 \\
\hline Musa cf parasidiaca Linn & Banana Serra-d'água & A & 1 \\
\hline Strelitzia reginae Banks (Eichemberg, M.T. $\mathrm{n}^{\circ} 200$ ) & ---/ Ave-do-paraíso & $\mathrm{O}$ & 1 \\
\hline \multicolumn{4}{|c|}{ Family: Myrsinaceae } \\
\hline Ardisia crenata Sims (Eichemberg, M.T. n 285, 511) & Green plant / Folhagem & $\mathrm{O}$ & 2 \\
\hline \multicolumn{4}{|c|}{ Family: Myrtaceae } \\
\hline Eugenia brasiliensis Lam. (Eichemberg, M.T. n 229 ) & ---/ Grumixama & A & 1 \\
\hline Eugenia involucrata DC. (Eichemberg, M.T. n ${ }^{\circ} 6$ ) & Cherry of the Rio Grande/ Cereja & A & 1 \\
\hline Eugenia pyriformis Camb. (Eichemberg, M.T. $\left.\mathrm{n}^{\circ} 101,524\right)$ & ---/ Uvalha/ Orvalha/ Uvaia & A & 2 \\
\hline Eugenia uniflora Linn (Eichemberg, M.T. n 8, 103, 598) & ---/ Pitanga & $\mathrm{A} / \mathrm{M}$ & 9 \\
\hline Myrciaria cauliflora Berg (Eichemberg, M.T. n 13, 77, 108) & ---/ *Jaboticaba/Sabará/Punhema & $\mathrm{A} / \mathrm{M}$ & 15 \\
\hline Myrciaria glomerata O. Berg (Eichemberg, M.T. n 4, 44, 131) & Cabelluda or yello jaboticaba/ Cabeludinha & A & 3 \\
\hline Psidium guajava Linn (Eichemberg, M.T. $\mathrm{n}^{\circ} 51$ ) & Strawberry guava/ Goiaba & $\mathrm{A} / \mathrm{M}$ & 10 \\
\hline Psidium cattleianum Sabine (Eichemberg, M.T. $\mathrm{n}^{\circ} 12,89,501$ ) & ---/ Araçá/goiabinha-do-mato/gabiroba & A & 4 \\
\hline Syzygium jambos (L.) Alston (Eichemberg, M.T. n 132, 529) & Rose apple/ Jambo & A & 2 \\
\hline \multicolumn{4}{|c|}{ Family: Nyctaginaceae } \\
\hline Bougainvillea spectabilis Willd. (Eichemberg, M.T. $\mathrm{n}^{\circ} 328,351$ ) & ---/ Primavera branca & $\mathrm{O}$ & 1 \\
\hline Mirabilis jalapa Linn (Eichemberg, M.T. n 683) & ---/ Maravilha/flor & $\mathrm{O}$ & 2 \\
\hline \multicolumn{4}{|c|}{ Family: Ochnaceae } \\
\hline \multicolumn{4}{|c|}{ Family: Oleaceae } \\
\hline Jasminum azoricum Linn (Eichemberg, M.T. $\mathrm{n}^{\circ} 259$ ) & Jasmime/ Jasmim & $\mathrm{O}$ & 1 \\
\hline Jasminum polyanthum Franch. & Jasmime/ Jasmim & $\mathrm{O}$ & 1 \\
\hline Jasminum sambac Sol. & ---/ Flor/jasmim mosqueta & $\mathrm{O}$ & 2 \\
\hline Osmanthus fragrans Lour. & ---/ Jasmim-do-imperador & $\mathrm{O}$ & 1 \\
\hline \multicolumn{4}{|c|}{ Family: Orchidaceae } \\
\hline Cypripedium calceolus Linn & ---/ Orquídea sapatinho & $\mathrm{O}$ & 2 \\
\hline Dendrobium nobile Lindl. & ---/ Orquídea olho de boneca & $\mathrm{O}$ & 12 \\
\hline Oncidium varicosum Lindl. & ---/ Orquídea chuva de ouro/bailarina & $\mathrm{O}$ & 6 \\
\hline \multicolumn{4}{|c|}{ Family: Oxalidaceae } \\
\hline Averrhoa carambola Linn (Eichemberg, M.T. $\mathrm{n}^{\circ} 52$ ) & Star friut/Carambola & A & 2 \\
\hline cf Oxalis sp1 & ---/ Avenca japonesa & $\mathrm{O}$ & 1 \\
\hline Oxalis sp2 & ---/ Trevo-de-quatro-folhas & Outros & 1 \\
\hline Oxalis sp3 (Eichemberg, M.T. n 307 ) & ---/ Trevo-roxo & $\mathrm{O}$ & 2 \\
\hline \multicolumn{4}{|c|}{ Family: Passifloraceae } \\
\hline Passiflora edulis Sims (Eichemberg, M.T. n 54, 613, 674) & Passionfruit/ Maracujá & A & 3 \\
\hline \multicolumn{4}{|c|}{ Family: Phytolaccaceae } \\
\hline Petiveria alliacea Linn (Eichemberg, M.T. n 112, 225) & ---/ Guiné/comigo-ninguém-pode & Out/O/M & 4 \\
\hline \multicolumn{4}{|c|}{ Family: Piperaceae } \\
\hline Peperomia obtusifolia A.Dietr. (Eichemberg, M.T. n 141, 167, 299) & Green plant / Folhagem & $\mathrm{O}$ & 4 \\
\hline Peperomia sandersii C.DC. (Eichemberg, M.T. n 149) & Watermelon/ Melancia & $\mathrm{O}$ & 1 \\
\hline Peperomia scandens Ruiz \& Pav. (Eichemberg, M.T. n 409) & Green plant / Folhagem & $\mathrm{O}$ & 1 \\
\hline Pothomorphe umbellata Miq. (Eichemberg, M.T. n²23, 182, 455) & ---/ Pariparoba/chapéu-de-couro & M & 4 \\
\hline \multicolumn{4}{|c|}{ Family: Plantaginaceae } \\
\hline Plantago major Linn (Eichemberg, M.T. n 549) & Natural antibiotic/ Antibiótico natural & M & 1 \\
\hline
\end{tabular}


Appendix 1 (Continuação).

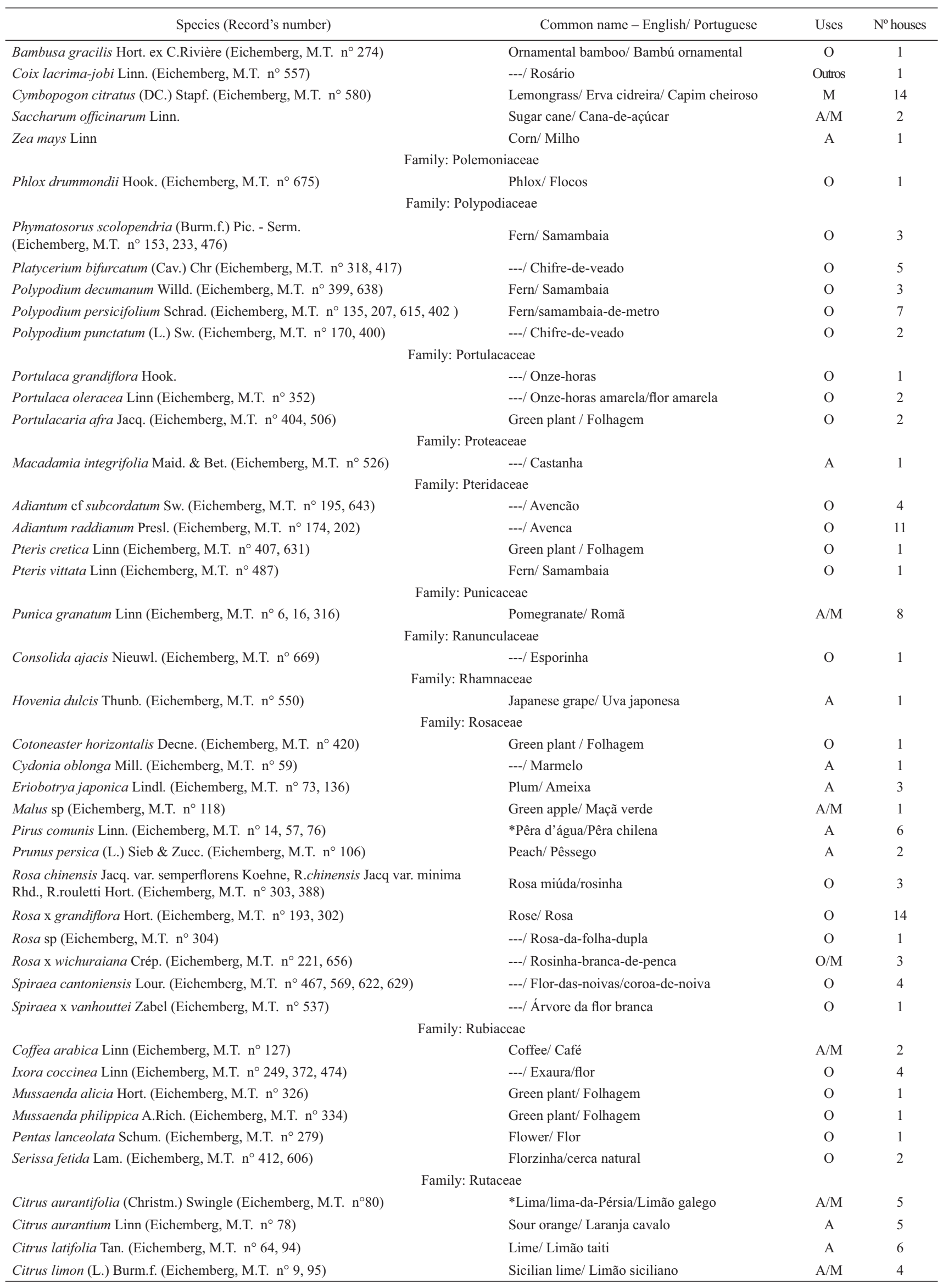


Appendix 1 (Continuação).

\begin{tabular}{|c|c|c|c|}
\hline Species (Record's number) & Common name - English/ Portuguese & Uses & $\mathrm{N}^{\mathrm{o}}$ houses \\
\hline Citrus limonia (L.) Osbeck (Eichemberg, M.T. n $63,62,96,544$ ) & Rangpur lime/ Limão cravo/ Limão rosa & A & 9 \\
\hline Citrus medica Linn (Eichemberg, M.T. $\mathrm{n}^{\circ}$ 79) & ---/ Cidra & A & 2 \\
\hline Citrus reticulata Blanco (Eichemberg, M.T. n 90, 91, 102) & $\begin{array}{l}\text { Orange/*Laranja cravo/Laranja pokan/Mixirica/ } \\
\text { Tangerina miúda }\end{array}$ & A & 9 \\
\hline Citrus sinensis (L.) Osbeck (Eichemberg, M.T. n 99, 115, 542, 612 ) & $\begin{array}{l}\text { Orange/*Laranja/ baía/baianinha/cristal/ lima/ } \\
\text { pêra/ São Sebastião }\end{array}$ & A & 9 \\
\hline Fortunella sp (Eichemberg, M.T. n 97) & ---/ Laranjinha quicã & A & 1 \\
\hline Murraya paniculata (L.) Jack (Eichemberg, M.T. $n^{\circ} 46$ ) & ---/ Murta/dama-da-noite & $\mathrm{O}$ & 3 \\
\hline Ruta graveolens Linn (Eichemberg, M.T. n 67, 642) & ---/ Arruda & Outro/M & 7 \\
\hline \multicolumn{4}{|c|}{ Family: Sapindaceae } \\
\hline Litchi chinensis Sonn. (Eichemberg, M.T. n 100, 145, 500) & ---/ Lichia/Uva-itália/Ameixa-do-Pará & A & 3 \\
\hline \multicolumn{4}{|c|}{ Family: Sapotaceae } \\
\hline Chrysophylum sp (Eichemberg, M.T. n 644) & African star apple/ Sapoti & $\mathrm{O}$ & 1 \\
\hline \multicolumn{4}{|c|}{ Family: Saxifragaceae } \\
\hline Hydrangea macrophylla Ser. (Eichemberg, M.T. n 155, 220) & Hydrangea/ Hortência & $\mathrm{O}$ & 9 \\
\hline \multicolumn{4}{|c|}{ Family: Scrophulariaceae } \\
\hline Russelia equisetiformis Schltdl. \& Cham. (Eichemberg, M.T. n²50) & ---/ Flor vermelha & $\mathrm{O}$ & 1 \\
\hline \multicolumn{4}{|c|}{ Family: Selaginellaceae } \\
\hline Selaginella umbrosa Hyeron. (Eichemberg, M.T. n 416 ) & Green plant / Folhagem & $\mathrm{O}$ & 1 \\
\hline \multicolumn{4}{|c|}{ Family: Solanaceae } \\
\hline Brugmansia suaveolens Bercht. \& Presl. (Eichemberg, M.T. n 681) & ---/ Trombeta & $\mathrm{M} / \mathrm{O}$ & 3 \\
\hline Brunfelsia uniflora D.Don. (Eichemberg, M.T. n 17, 469,657) & ---/ Manacá & $\mathrm{O}$ & 4 \\
\hline Capsicum annuum Linn & Red pepper/ Pimentão vermelho & A & 1 \\
\hline Capsicum frutescens Linn (Eichemberg, M.T. n 98, 324, 546) & ---/ *Pimenta dedo-de-moça/ malagueta & A & 5 \\
\hline Capsicum chinense Jacq. & ---/ Pimenta chapéu-de-frade & A & 1 \\
\hline Capsicum baccatum Linn (Eichemberg, M.T. n46) & ---/ Pimenta cambari/dedo-de-moça & A & 4 \\
\hline Cestrum nocturnum Linn (Eichemberg, M.T. n³91,570) & ---/ Dama-da-noite & $\mathrm{O}$ & 2 \\
\hline Lycopersicon pipinellifolium Mill. (Eichemberg, M.T. n²28, 310) & Cherry tomato/ Tomate cereja & A & 2 \\
\hline Solanum albidum Dun. (Eichemberg, M.T. n 3, 597, 625) & ---/ Jurubeba & M & 2 \\
\hline Solanum americanum Mill. (Eichemberg, M.T. n 260) & ---/ Maria-preta & $\mathrm{O}$ & 1 \\
\hline Solanum pseudocapsicum Linn (Eichemberg, M.T. n 475) & ---/ Bolinha vermelha & $\mathrm{O}$ & 1 \\
\hline Solanum seaforthianum Andr. (Eichemberg, M.T. n² 248) & Vine/ Trepadeira & $\mathrm{O}$ & 1 \\
\hline \multicolumn{4}{|c|}{ Family: Theaceae } \\
\hline Camellia japonica Linn (Eichemberg, M.T. n 246 ) & ---/ Camélia & $\mathrm{O}$ & 1 \\
\hline \multicolumn{4}{|c|}{ Family: Thelypteridaceae } \\
\hline Thelyptens dentata (Forssk.) E.P.St.John (Eichemberg, M.T. n 180) & Fern/ Samambaia & $\mathrm{O}$ & 1 \\
\hline \multicolumn{4}{|c|}{ Family: Tropaeolaceae } \\
\hline Tropaeolum majus Linn (Eichemberg, M.T. n ${ }^{\circ 44)}$ & Flower/Flor & $\mathrm{O}$ & 2 \\
\hline \multicolumn{4}{|c|}{ Family: Urticaceae } \\
\hline Parietaria officinalis Linn (Eichemberg, M.T. $\mathrm{n}^{\circ} 128,585$ ) & ---/ Palitária & M & 2 \\
\hline Pilea microphylla Liebm. (Eichemberg, M.T. n 422) & Green plant / Folhagem & $\mathrm{O}$ & 1 \\
\hline Pilea nummularifolia Wedd. (Eichemberg, M.T. n²34) & ---/ Dinheiro-em-penca & $\mathrm{O}$ & 1 \\
\hline \multicolumn{4}{|c|}{ Family: Verbenaceae } \\
\hline Clerodendron thomsonae Balf. (Eichemberg, M.T. n 325) & Brinco-de-princesa & $\mathrm{O}$ & 1 \\
\hline Clerodendron x speciosum Tiejism. \& Binn. (Eichemberg, M.T. n 333,659 ) & Brinco-de-princesa & $\mathrm{O}$ & 1 \\
\hline Duranta repens Linn “Aurea” (Eichemberg, M.T. n 371, 451) & Pingo-de-ouro/cerca viva/piriquito & O/Outros & 3 \\
\hline Lantana camara Linn (Eichemberg, M.T. n 317 ) & Flor/macela & $\mathrm{O} / \mathrm{M}$ & 2 \\
\hline Lippia alba (Mill.) N.E.Br. (Eichemberg, M.T. n²2, 236) & Melissa & M & 4 \\
\hline Petrea subserrata Cham (Eichemberg, M.T. n 11, 253, 588) & Flor-de-São Miguel & $\mathrm{O}$ & 2 \\
\hline Stachytarpheta cayennensis (L.P.Rich) Vahl. (Eichemberg, M.T. $\mathrm{n}^{\circ} 558,686$ ) & Gerbão & M & 1 \\
\hline \multicolumn{4}{|c|}{ Family: Violaceae } \\
\hline Viola odorata Linn (Eichemberg, M.T. n 104, 565) & Violeta & M & 2 \\
\hline \multicolumn{4}{|c|}{ Family: Vitaceae } \\
\hline
\end{tabular}


Appendix 1 (Continuação).

\begin{tabular}{|c|c|c|c|}
\hline Species (Record's number) & Common name - English/ Portuguese & Uses & $\mathrm{N}^{\mathrm{o}}$ houses \\
\hline \multicolumn{4}{|c|}{ Family: Zingiberaceae } \\
\hline Curcuma longa Linn (Eichemberg, M.T. $\mathrm{n}^{\circ} 405,605$ ) & Açafrã & A & 1 \\
\hline Zingiber officinale Roscoe (Eichemberg, M.T. $n^{\circ} 21$ ) & Gengibre & $\mathrm{A} / \mathrm{M}$ & 11 \\
\hline Indet & Arbusto & $\mathrm{O}$ & 1 \\
\hline Indet & Flor & $\mathrm{O}$ & 1 \\
\hline Indet & Folhagem & $\mathrm{O}$ & 1 \\
\hline Indet & Folhagem & $\mathrm{O}$ & 1 \\
\hline indet & Romeu e Julieta/árvore & $\mathrm{O} /$ Outros & 2 \\
\hline
\end{tabular}

*Varieties

$\mathrm{O}=$ Ornamental, $\mathrm{A}=$ Alimentary, $\mathrm{M}=$ Medicinal, Out $=$ Other uses 